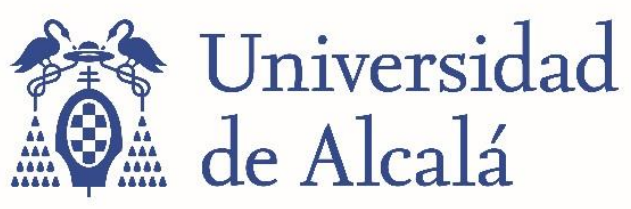

BIBLIOTECA

Document downloaded from the institutional repository of the University of Alcala: http://dspace.uah.es/dspace/

This is the peer reviewed version of the following article:

Pérez-Camacho, Lorenzo et al., 2018. Structural complexity of hunting habitat and territoriality increase the reversed sexual size dimorphism in diurnal raptors. Journal of avian biology, 49(10), pp.e01745-n/a., which has been published in final form at https://doi.org/10.1111/jav.01745 .

This article may be used for non-commercial purposes in accordance with Wiley Terms and Conditions for Use of Self-Archived Versions.

(C) 2018 Wiley

(Article begins on next page)

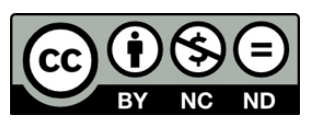

This work is licensed under a

Creative Commons Attribution-NonCommercial-NoDerivatives

4.0 International License. 


\section{Structural complexity of hunting habitat and territoriality increase the reversed sexual size dimorphism in diurnal raptors}

\begin{tabular}{|c|c|}
\hline Journal: & Journal of Avian Biology \\
\hline Manuscript ID & JAV-01745.R2 \\
\hline Wiley - Manuscript type: & Article \\
\hline Keywords: & Body size, life-history traits, sexual size dimorphism (SSD) \\
\hline Abstract: & $\begin{array}{l}\text { Despite numerous efforts and many hypotheses to explain the selective } \\
\text { pressures that may have favoured reversed sexual dimorphism (RSD) in } \\
\text { raptors - i.e. that the female is larger than the male - some drivers of RSD } \\
\text { are still unknown. } \\
\text { Here we analyse how much variation in RSD is explained by hunting } \\
\text { habitat structure, territoriality or territory size. We do so using data on } \\
\text { diurnal raptors from the New World and the Western Palearctic - i.e. } \\
\text { Cathartidae, Pandionidae, Accipitridae and Falconidae, the largest bird } \\
\text { group showing RSD - taking into account the phylogenetic relationships } \\
\text { among species. } \\
\text { Our results identify the type of the main prey as a major factor explaining } \\
\text { RSD in raptors. We also found RSD to increase with increasing structural } \\
\text { complexity in the hunting habitat from open or semi-open habitats to } \\
\text { forest interior. RSD also increased with increasing degree of territoriality of } \\
\text { the species (non-territorial < facultative < territorial). Finally, for territorial } \\
\text { species RSD increased with increasing size of nesting territory. A model } \\
\text { comprising only three predictor variables (prey type, structural complexity } \\
\text { of hunting habitat and territoriality) explained up to } 50 \% \text { of the variation in } \\
\text { RSD of European and American diurnal raptor species, and up to } 40 \% \text { of } \\
\text { the variation in RSD when only territorial species were considered. } \\
\text { Our results highlight the relevance of spatial facets of the niche - e.g. } \\
\text { hunting habitat, territoriality and territory size - in exerting selective } \\
\text { pressures on the body size of diurnal raptors. These selective pressures, } \\
\text { joint with already known trophic factors - e.g. diet - are decisive for the } \\
\text { evolution of the RSD, a key trait in the functional ecology of raptors. Our } \\
\text { findings open up new perspectives in the study of sexual size divergence in } \\
\text { birds. }\end{array}$ \\
\hline
\end{tabular}




\section{Abstract}

2 Despite numerous efforts and many hypotheses to explain the selective pressures that may have

3 favoured reversed sexual dimorphism (RSD) in raptors - i.e. that the female is larger than the

4 male - some drivers of RSD are still unknown.

5 Here we analyse how much variation in RSD is explained by hunting habitat structure,

6 territoriality or territory size. We do so using data on diurnal raptors from the New World and the

7 Western Palearctic - i.e. Cathartidae, Pandionidae, Accipitridae and Falconidae, the largest bird

8 group showing RSD - taking into account the phylogenetic relationships among species.

9 Our results identify the type of the main prey as a major factor explaining RSD in raptors. We

10 also found RSD to increase with increasing structural complexity in the hunting habitat from

11 open or semi-open habitats to forest interior. RSD also increased with increasing degree of

12 territoriality of the species (non-territorial $<$ facultative $<$ territorial). Finally, for territorial

13 species RSD increased with increasing size of nesting territory. A model comprising only three

14 predictor variables (prey type, structural complexity of hunting habitat and territoriality)

15 explained up to $50 \%$ of the variation in RSD of European and American diurnal raptor species,

16 and up to $40 \%$ of the variation in RSD when only territorial species were considered.

17 Our results highlight the relevance of spatial facets of the niche - e.g. hunting habitat,

18 territoriality and territory size - in exerting selective pressures on the body size of diurnal raptors.

19 These selective pressures, joint with already known trophic factors - e.g. diet preference-are

20 decisive for the evolution of the RSD, a key trait in the functional ecology of raptors. Our

21 findings open up new perspectives in the study of sexual size divergence in birds.

22 Keywords: Body size, life-history traits, sexual size dimorphism (SSD). 


\section{Introduction}

24 Understanding the selective pressures that cause sex differences in life history is a fundamental 25 question in ecology (Sutherland et al. 2013). Among most of diurnal raptors (Cathartidae,

26 Pandionidae, Accipitridae and Falconidae), body size is one of the most notable differences

27 between males and females. Raptors generally show female-biased sexual size dimorphism, an

28 opposite trend to what is observed in most bird and mammal species, thus usually termed

29 reversed sexual dimorphism (hereafter RSD) (Amadon 1959; Andersson and Norberg 1981;

30 Székely et al. 2007). Even so, RSD varies widely among different species of raptors. While some

31 species show barely noticeable differences between sexes, in others, females are twice as heavy

32 as their partners (Newton 1979).

33 Numerous hypotheses have been proposed to explain what selective pressures may cause RSD in

34 raptors (Massemin et al. 2000; Ferguson-Lees and Christie 2001; and-Krüger 2005; Slagsvold 35 and Sonerud 2007; Sonerud et al. 2013). However, despite the abundant literature on RSD, the

36 mechanisms favouring this trait remain elusive (Ferguson-Lees and Christie 2001; Sonerud et al.

37 2013; Friedman and Remeš 2016) partly because several potential drivers of RSD are yet to be

38 evaluated. For instance, the relationships between RSD and relevant raptor characteristics such

39 as the structural complexity of the hunting habitat, the degree of territoriality, and territory size

40 have received little attention (Snyder and Wiley 1976; Walter 1979; Pérez-Camacho et al. 2015;

41 Table 1). Novel empirical evidence on the causal factors of RSD is required to better understand

42 the evolution of body size, not only in diurnal raptors, but also in other groups of birds showing

43 RSD (Jehl and Murray 1986; Székely et al. 2000; Sonerud et al. 2014a).

44 A widely accepted hypothesis for RSD posits that it responds to differentiated sex roles during

45 the breeding season (Storer 1966; Reynolds 1972; Andersson and Norberg 1981; Slagsvold and 
46 Sonerud 2007; Sonerud et al. 2014a). It is well known that in raptors, the female usually

47 incubates, broods and feeds the nestlings, until they can feed themselves unassisted, while the male provides food for the family (Newton 1979). Greater difference in sex roles implies a

49 greater potential for differential selection on male and female body size. Sonerud et al. (2014a) showed that prey size conditions the period of time in which chicks have to be fed by the femaleshould eat female-assisted. Large preys cannot be managed by the chicks until they reach an advanced age, delaying the time at which females resume to hunting (Sonerud et al. 2014a, b).

53 As a result, males would need to provide a frequent and abundant supply of food for the whole

54 family, especially after the eggs hatch (Newton 1979; del Hoyo et al. 1994). Selective pressures

55 would have driven males to increase their hunting efficiency by hunting smaller prey, which are

56 often more abundant than larger prey (Storer 1966). If true, male raptor size would decrease

57 because smaller prey species are usually more agile than larger prey and, because smaller

58 predators are more agile and more efficient at capturing small prey (Reynolds 1972; Andersson

59 and Norberg 1981; Ferguson-Lees and Christie 2001; Dial et al. 2008; Tornberg et al. 2014).

Male size reduction, would ultimately improve reproductive success (Ydenberg and Forbes

1991) by increasing efficiency at hunting smaller prey.

62 Prey type and size is recurrently utilised as a proxy for mechanisms underlying the variation in

63 RSD among species of raptors. For example, several works have documented the effect of prey

64 type, as a surrogate for prey agility, on RSD, suggesting that the higher the speed and agility of

65 the main prey of the raptor, the greater its RSD (Hill 1944; Reynolds 1972; Newton 1979;

66 Wheeler and Greenwood 1983; Temeles 1985; Paton et al. 1994). Additionally, Sonerud et al.

67 (2014a, 2014b) showed that prey type can act as a proxy for prey handling time given the

68 positive correlation between prey agility and prey handling time (Sonerud et al. 2014a). The 
69 longer the handling time, the longer the female is confined to the nest, which would in turn lead 70 to greater RSD values.

71 Other explanatory factors for RSD variation have received much less attention. For example,

72 there is little information on how the structural complexity of the habitat affects hunting success,

73 male raptor size and- RSD. We hypothesise that structurally complex habitats such as forest

74 interiors, where many obstacles must be avoided during hunting, would exert an additional

75 pressure on males to become smaller in order to increase their agility, akin to the pressure due to

76 prey agility. This hypothesis predicts that RSD is greater among forest-dwelling raptors than

77 among raptors inhabiting open habitats such as steppes, savannahs and deserts, which present

78 few obstacles to hunting.

79 Another little-studied factor that may affect RSD is territoriality. Territoriality is an extreme case

80 of intra-specific competition in which certain individuals are able to breed by controlling a

81 portion of the habitat, while those that fail to occupy a territory often do not contribute offspring

82 to the next generation (Brown 1964). Most raptor species (75\% of the genera) are territorial

83 during the breeding season (Newton 1979; del Hoyo et al. 1994; Ferguson-Lees and Christie

84 2001; Rebollo et al. 2017). If territorial disputes are resolved based on aerial agility, territoriality

85 should promote a reduction in the size of competing individuals. That is, smaller male size would

86 translate into greater aerial agility and thus, into greater likelihood of gaining access to nesting

87 territories through effective flight displays (Andersson and Norberg 1981; Widén 1984;

88 Hakkarainen et al. 1996; Székely et al. 2007). Alternatively, if territorial disputes are resolved

89 through force, territoriality may promote an increase in body size, i.e the larger the female, the

90 greater its effectiveness in competing with other females for the best males and their nesting

91 territories (Olsen and Olsen 1987; McDonald et al. 2005; Sergio et al. 2007; Pérez-Camacho et 
92 al. 2015). These hypotheses propose that territorial species could experience extra selective

93 pressures related to nesting in relation to non-territorial raptors. These additional pressures may

94 promote RSD.

95 There are few data to test whether territoriality promotes an increase in RSD and, if so, whether

96 RSD increases through an increase in female size, a reduction in male size, or both (Olsen and

97 Olsen 1987; McDonald et al. 2005; Sergio et al. 2007; Pérez-Camacho et al. 2015). The same

98 can be said of the potential effect of nesting territory size on RSD, which is tightly linked to

99 territoriality. For a territorial species, the size of the nesting territory determines the number of

100 reproductive pairs in a given area (Patterson 1980; Newton 2003). Therefore, if two species have

101 the same population size but occupy territories of different sizes, then the proportion of breeding

102 adults should be smaller in the species occupying the larger territories. As a result, the selective

103 pressures on traits that promote access to breeding territories should increase with increasing size

104 of nesting territory. Whether and how this increased pressure affects RSD is yet to be examined.

105 Here, we test the relative ability of four hypotheses to explain interspecific variation in RSD of

106 diurnal raptors from the New World and the Western Palearctic (see Table 1 for a summary).

107 First, the prey agility hypothesis, which poses that prey agility influences male size because

108 smaller males are more effective at capturing agile prey. This hypothesis predicts a positive

109 correlation between raptor RSD and the agility of the prey, measured by the taxonomic grouping

110 to which the main prey belongs. Second, the habitat complexity hypothesis states that complexity

111 may induce RSD in raptors because forest interiors would favour hunting of smaller males. The

112 prediction is for male size to decrease with increasing structural complexity of the hunting

113 habitat during the breeding season. Third and fourth, the territoriality and territory size

114 hypotheses, respectively, which expect territoriality to affect RSD through larger females and/or 
115 smaller males being more effective at establishing nesting territories when there is a spatial

116 constraint on nesting. The derived prediction is that territorial species and, within territorial

117 species those defending the largest territories, will show higher values of RSD. We take into

118 account the phylogenetic non-independence among raptor species, both when we explore

bivariate relationships of RSD against each proxy and when we test these hypotheses in a multiple regression setting.

\section{Materials and methods}

\section{Data collection}

124 We collated data on New World and Western Palearctic diurnal raptor species from numerous

125 data sources (see Supplementary material Appendix 1); the data encompassed a wide range of

126 habitats and life histories. RSD was calculated for each species using the arithmetic midpoint

127 between the minimal and maximal body masses given in each sex (mid-range) and the following

128 index based on Storer (1966): RSD Index $=100 \times[($ female mass - male mass $) /(0.5 \times($ female

129 mass + male mass))]. In parallel, the RSD index was calculated using the mid-range of the cubed

130 wing length, in order to compare our results with previous studies on RSD that used wing length

131 as a surrogate for body mass (Ferguson-Lees and Christie 2001 and Krüger 2005).

132 We assessed the ability of fFour factors linked to our hypotheses (see above) were assessed for their ability-to predict explain the-variation in RSD for raptors: (1) prey agility, which was scored according to each species' main prey (mainly based on the diet description found in Ferguson-

135 Lees and Christie 2001 and del Hoyo et al. 1994), following a 6-point scale in ascending order of

136 prey agility [ $1=$ carrion (including eggs, nestlings and injured prey), $2=$ invertebrates, $3=$

137 reptiles and amphibians, $4=$ fish, 5 = mammals, $6=$ birds] ( $\underline{\text { sensu }}$ Temeles 1985, but including 
138 carrion and amphibians + reptiles); further studies should refine the prey agility index when accurate data on the proportional composition of the diet becomes available for each of the studied species; (2) structural complexity of hunting habitat, (mainly based on the habitat description found in Ferguson-Lees and Christie 2001 and del Hoyo et al. 1994) which was 142 assessed on a 3-point scale [ 1 = open habitat (e.g. hunting takes place exclusively or mainly in 143 open landscapes such as desert, savanna, or over the tree canopy), $2=$ semi-open habitat (e.g. 144 mosaic of fields and forests or the ecotone between them), $3=$ closed habitat (e.g. hunting takes 145 place exclusively or mainly inside forests)]; (3) territoriality, characterised as the average extent 146 of nesting territorial behaviour during the breeding season on a 3-point scale [ $0=$ non-territorial 147 (species that breed in colonies or loose colonies), $1=$ facultative (breeding behaviour varies 148 between non-territorial and territorial among different populations of the same species), $2=$ 149 territorial (solitary species that defend an area containing the nest and usually some food 150 resources as well)] (for data sources see Supplementary material Appendix 1); and (4) territory 151 size (for the subset of territorial species), expressed as an index reflecting the territory size per 152 unit body mass:

153 Territory size index $=$ mean nearest neighbour nest distance $/ \log _{10}$ (mid-range of male body 154 mass)

155 This index takes into account the relationship between territory size and species body mass 156 among the species studied here (data not shown; $r=0.611, \mathrm{p}<0.001$; Schoener 1968; Newton 157 1979; Palmqvist et al. 1996). Male body mass was used to calculate the territory size index 158 because it explained more variation in RSD than female body mass or the mean body mass of 159 both sexes (Supplementary material Appendix 2. Figure A1). Data on distances among nests 160 were extracted from a literature review conducted by searching the databases of the Web of 
161 Science, Zoological Record and Wildlife and Ecology Studies Worldwide. The following search

162 terms were used: nest distance OR distribution OR spacing OR dispersion OR territory, spatial

163 pattern OR distribution OR nearest neighbour AND raptor OR < the name of each raptor group

$164>$. Of the more than 850 papers identified, we retained 123 (see Supplementary material

165 Appendix 1) and extracted distance data for territorial species, allowing us to calculate the

166 territory size index.

167 Our goal is to test a parsimonious model, i.e. with few variables of high explanatory powerhigh explanatory variables, which have not been examined to date (with the exception of prey type), rather than a comprehensive model with many variables, most of them with poorly explanatory

170 power, which has already been tested (e.g. Krüger 2005).

\section{Statistical analyses}

172 Since our goal was not to build accurate predictive models but rather to understand the

173 relationships between RSD and predictor variables, we followed a two-pronged approach.

174 Firstly, we inspected the bivariate relationships between RSD and each of our predictor

175 variables, each of them supported by a well-founded hypothesis. Secondly, we used saturated 176 ordinary least squares (OLS) models to analyse the associations of RSD with the four predictors

177 (prey agility, hunting habitat, territoriality or territory size). Standardised regression coefficients

178 and the associated $p$-values were used to approximate the strength with which variables were

179 associated with RSD. To evaluate the extent to which collinearity among predictors affected our

180 models, we calculated their condition number; a condition number greater than five indicates

181 unstable regression coefficients (Belsley 1991). We also performed OLS partial regressions to

182 calculate the amount of variation in RSD explained by each predictor either independently or 183 jointly with the other predictors. 
184 We repeated all analyses for two sets of species. Of the approximately 135 species inhabiting the 185 study regions (del Hoyo et al. 1994; Ferguson-Lees and Christie 2001), the first set comprised 75

186 territorial, facultative and non-territorial species for which we had complete data on all variables,

187 including phylogenetic data. The distribution of RSD across studied raptor species was normal

188 without any signs of skewness (Supplementary material Appendix 3. Figure A4). Future studies

189 should seek to determine whether our results are also valid for a global set of diurnal raptor

190 species. The second set focused on the 36 territorial species for which we also had data on

191 territory size. This procedure allowed us to investigate our hypotheses not only for a

192 comprehensive set of species to assess the extent to which territoriality associates with RSD, but

193 also for the subset of territorial species to infer whether species defending larger territories show

194 greater RSD. A percentage response variable such RSD should be modelled using GLS models

195 with logit link function for the residuals. However, the statistical distribution of RSD, analogous

196 to a continuous response variable allowed us modelling it using OLS. First, RSD is normally

197 distributed as supported by Shapiro-Wilk normality tests for both the $75(P=0.504)$ and the 36

$198(P=0.652)$ species subsets. Second, most of RSD data fall within the linear section of the

199 sigmoidal logistic curve (i.e. between 0.2 and 0.8 ) and thus, all predicted values are within 0 and $200 \quad 100 \%$.

\section{Phylogenetic analyses}

202 To account for phylogenetic autocorrelation, we compared the results of the abovementioned 203 OLS models with those of phylogenetic generalized least squares (PGLS) models (Freckleton et

204 al. 2002). PGLS models are a special type of generalized least squares model that accounts for 205 phylogenetic correlation structure in model residuals, represented by a phylogenetic variance206 covariance matrix. We fitted PGLS models by making maximum likelihood-based adjustments 
207 to the evolutionary scaling parameters $\lambda$ and $\delta$ (Pagel 1999). The parameter $\lambda$ indicates the fit of a

208 trait to a Brownian evolutionary model; in other words, the parameter assesses the extent to

209 which evolutionary relatedness leads to patterns of trait similarity. It ranges from zero (absence

210 of phylogenetic signal) to one (perfect fit to Brownian motion). The parameter $\delta$ is the power to

211 which the elements of the variance-covariance matrix are raised and it characterises the tempo of

212 evolution. Whereas a default value of $\delta=1.0$ indicates linear change in the trait that is

213 proportional to branch length, values of $\delta<1.0$ suggest an early evolution of the trait, while

214 values of $\delta>1.0$ suggest a more recent evolution (Pagel 1999). This analysis allows us to

215 determine whether model residuals contain phylogenetic signal, and it also indicates the extent to

216 which we can rely on the significance of OLS regression coefficients. We extracted data on the

217 phylogenetic relationships for the set of 75 species of raptors considered, and for the subset of 36

218 territorial species from the recent avian phylogeny published by Jetz et al. (2012). We computed

219 the phylogenetic variance-covariance matrices that allowed calculation of $\lambda, \delta$ and PGLS models.

220 We accounted for non-phylogenetic independence between species also in the bivariate analyses

221 of RSD with predictor variables.

222 To compare our models against models lacking the assumptions made by PGLS - i.e. Brownian

223 Motion as the model of reference - we fitted a Generalized Mixed Model in a Bayesian

224 framework using Markov Chain Monte Carlo (MCMC) (Hadfield and Nakagawa 2010). In this

225 modelling framework, phylogenetic relationships are included as a random effect rather than as a

226 variance-covariance matrix expressing the phylogenetic structure in model residuals (see

227 Appendix 4. Table A1).

228 We calculated the significance of correlations after correcting the number of degrees of freedom

229 using Dutilleul's (1993) method implemented in SAM 4.0 (Rangel et al. 2010) and using a 
230 phylogenetic ANOVA (Garland et al. 1993). Phylogenetic analyses were performed in R 3.3.0

231 (R Development Core Team) using the packages 'ape' (Paradis et al. 2004), 'caper' (Orme et al.

232 2013), 'MCMCglmm' (Hadfield 2010) and 'phytools' (Revell 2012). Figures depicting partial

233 regressions were generated using the eulerAPE area-proportional Euler diagram application

234 (Micallef and Rodgers 2014). Data available from the Supplementary material Appendix 1, 235 Table A1.

\section{Results}

238 Analysis of bivariate relationships between RSD and predictors revealed that diurnal raptors that 239 hunt more agile prey had higher RSD than raptors that hunt less agile or immobile prey $(r=$ 2400.658 , corrected-p $<0.001$; Fig. 1a). Species that hunt in forest interiors showed greater RSD 241 than species hunting in open or semi-open habitats $(r=0.328$, corrected-p $=0.017$; Fig. $1 b)$.

242 Species that are territorial during the breeding season showed the greatest RSD, followed by 243 facultative species, and finally by non-territorial species, which showed the smallest RSD $(r=$ 2440.400 , corrected-p $=0.002$; Fig. $1 \mathrm{c}$ ). Among the subset of 36 territorial raptors, RSD positively 245 correlated with mean territory size index $(r=0.434$, corrected- $\mathrm{p}=0.011 ;$ Fig. 2$)$. The strength 246 and significance of bivariate associations between RSD and the predictors were virtually 247 identical when analysed based according to a phylogenetic ANOVA (Garland et al. 1993; see

248 Fig. 1). Further, we obtained similar results regardless of whether RSD was calculated using 249 body mass or cubed wing length, though RSD calculated with body mass was higher $(F=9.31 ; \mathrm{p}$ $250=0.003$ ) and more sensitive to the explanatory variables used in this study than the RSD 251 calculated using cubed wing length (Figs. 1 and 2, and Supplementary material Appendix 3, 252 Figs. A1-A3). 
253 Strength of the associations of RSD with the four predictors, as measured by standardised

254 regression coefficients, were consistent across OLS and PGLS models and across both sets of

255 species (Table 2). Prey agility was associated with the highest standardised regression

256 coefficients, followed by hunting habitat; these coefficients were significant for OLS and PGLS

257 models. Territoriality and territory size showed the smallest coefficients, which in no case

258 achieved statistical significance in a multiple linear modelling framework. Collinearity among

259 predictors did not affect the stability of regression coefficients since condition numbers were $<5$

260 (i.e. 1.662 for the full set of 75 species and 2.027 for the subset of 36 territorial species). To

261 check for the robustness of our prey agility classification, we run sensitivity analyses slightly

262 modifying the classification of prey types whose agility may be more dubious - e.g. fish being

263 more agile than reptiles and vice versa or merging amphibians, reptiles and fish into a single

$\underline{\text { lower-vertebrate category. Sensitivity analyses yielded virtually identical model coefficients and }}$

$\underline{\text { significations in both OLS and PGLS models (results not shown to avoid redundancy), }}$

confirming that our results are robust to subtle changes in our classification of prey agility.

267 To fit the PGLS models, we performed maximum likelihood-based adjustment of the

268 evolutionary parameters $\lambda$ and $\delta$; for both species sets, $\lambda$ was greater than 0.8 and $\delta$ was greater

269 than 1.0. These values suggest that the unexplained portion of RSD still contains non-random

270 phylogenetic signal, with closely related species tending to share similar RSD. Besides, RSD of

271 closely related species probably evolved non-linearly, with differences in RSD across species

272 accumulating over relatively recent times (i.e. $\delta>1.0$ ). Taking the phylogenetic non-

273 independence of species into account in the PGLS analysis did not appreciably affect the ranking

274 of standardised coefficients for each predictor (Table 2). 
275 OLS partial regressions confirmed that prey agility explained a larger proportion of RSD

276 variation than the other three predictors, which independently; explained proportions of RSD

277 variation according to the ranking of their OLS and PGLS regression coefficients (multiple

278 regression models; Fig. 3). Interestingly, territoriality and territory size explained a greater total

279 amount of RSD variation than hunting habitat. However, the variation explained by these two

280 territorial predictors partially overlapped with the variation in RSD explained by prey agility,

281 which was $14.1 \%$ for the complete set of 75 species and $16.7 \%$ for the subset of 36 territorial

282 species (Fig. 3 and Supplementary material Appendix 3, Table A1). For this reason, both

283 territorial variables are less important than hunting habitat within a multiple modelling context.

284 These results were qualitatively identical to those from PGLMM where phylogenetic

285 relationships were modelled as a random effect (see Appendix 4 for details).

\section{Discussion}

288 Our results, for the first time, provide empirical evidence that RSD in diurnal raptors positively

289 correlates with the structural complexity of the hunting habitat, as well as with territoriality.

290 Notably, these results encompass a broad range of raptor species and the large geographical

291 extent. The associations we find do not seem to be affected by the evolutionary relatedness

292 among species; they seem more likely to have appeared as an adaptive response to the ecological

293 factors on which this study focused.

\section{Relative importance of ecological factors}

295 The relationships between RSD and the predictors hold regardless the evolutionary relationships

296 among species, and despite the fact that raptor RSD is a strongly phylogenetically structured

297 trait. This means that closely related raptor species may have evolved RSD in response to similar 
298 selective pressures (Paton et al. 1994; Krüger 2005), some of which are analysed here. No more than $\Theta$ nly three predictor variables together explain up to $50 \%$ of the variation in RSD across the entire set of New World and Western Palearctic diurnal raptor species; up to $40 \%$ of RSD variation when only territorial species are considered. That is, a reduced number of mechanisms

302 (i.e. 3) would suffice to largely explain the evolution and maintenance of RSD in birds of prey

303 (for reviews, see Massemin et al. 2000; Ferguson-Lees and Christie 2001; Krüger 2005; and 304 Slagsvold and Sonerud 2007).

305 That RSD increases with increasing prey agility is widely accepted (Hill 1944; Storer 1966;

306 Reynolds 1972; Newton 1979; Temeles 1985; Ydenberg and Forbes 1991; Tornberg et al. 1999;

307 Massemin et al. 2000; Krüger 2005), and the prey agility hypothesis is supported by our results

308 based on a relatively large number of species distributed over a large geographical area.

309 Alternatively, our measurement of prey agility based on taxonomic grouping can also be seen as

310 a proxy for ingestion rate sensu Slagsvold and Sonerud (2007). Avian prey would take longer to

311 ingest than mammalian prey, mammals would take longer to ingest than reptiles, and reptiles

312 longer than insects (Slagsvold and Sonerud 2007, Slagsvold et al. 2010, Sonerud et al. 2014a, b).

313 Consequently, ingestion rate would explain RSD in the same direction as prey agility does, at

314 least when prey agility is measured based on taxonomy.

315 Our work identifies new ecological factors that influence RSD both jointly with prey agility and

316 independently of it. For example, the structural complexity of the hunting habitat, an overlooked

317 variable so far, explains $11 \%$ of the variation in RSD mostly independent of its association with

318 prey agility. This result suggests that, species feeding on agile prey inside complex habitats may

319 show the greatest RSD, and thus, that the selective pressures exerted by prey agility and habitat

320 complexity may be cumulative. Note that habitat preference (for example, used by Krüger 2005) 
321 is not equivalent to the structural complexity of the hunting habitat. For example, some raptor

322 species breeding in forests hunt over the canopy or in the forest edges. In fact, Krüger (2005) did

323 not find support for habitat preference as a driver of RSD.

324 The association between RSD and prey agility partially overlaps with the association between

325 RSD and species territoriality. In other words, part of the variation in RSD is explained jointly by

326 both predictors. This is not entirely surprising in the case of diurnal raptors, since species of this

327 group that capture more agile prey are more likely to show territorial behaviour than species

328 capturing more vulnerable prey (Nilsson et al. 1982; Martínez-Hesterkamp et al. in press2018).

329 Territorial behaviour and prey type could increase RSD in a species through different

330 mechanisms. The scarcity of studies analysing the relationships between RSD and territoriality

331 and territory size may have led researchers to overestimate the effects of prey-type based

332 mechanisms on RSD. Territoriality and territory size explained more absolute RSD variation in

333 partial regressions than did the structural complexity of hunting habitat (Fig. 3), even though

334 their regression coefficients were non-significant in multiple linear models. These findings,

335 together with the significant correlation between RSD and territoriality and territory size (Figs.

$3361 \mathrm{c}, 2$ ), advise to take these spatial factors into account, yet few studies have done so (Snyder and

337 Wiley 1976; Walter 1979; Widén 1984).

\section{Hunting habitat structure}

339 Our results identify that hunting habitats with high structural complexity affect RSD in raptors.

340 This supports our initial hypothesis that agility needed to catch prey effectively in an

341 environment with obstacles (i.e. forest interior) selects for the most agile males, which should be

342 smaller. Such selective pressure should increase the RSD of species that hunt within closed

343 habitats, while negligibly affecting the RSD of species that hunt in habitats with fewer obstacles 
344 (i.e. open habitats such as savannahs, steppes or deserts). On the other hand, we observed similar

345 RSD for species hunting in open as for species hunting in mixed habitats. This may indicate that

346 only habitats of greater structural complexity exert sufficient selective pressure to drive RSD.

347 If highly complex habitats select for smaller body size, it could in principle lead to a size

348 reduction in both sexes. Instead, we observed higher RSD in forest hunters, suggesting that the

349 size reduction occurred primarily or exclusively in males. This likely reflects the fact that raptor

350 RSD is influenced by hunting efficiency specifically during the early stages of the breeding

351 season, including the pre-breeding period, egg-laying, incubation, and first halfof the nestling

352 period (Newton and Marquiss 1984; Pérez-Camacho et al. 2015). During this period the male

353 bears nearly sole responsibility for hunting, leading the male to be more strongly selected for

354 small size than the female (Ferguson-Lees and Christie 2001; Sonerud et al. 2014a, b). Our

355 findings are consistent with previous research advocating for greater selective pressures on male

356 size than on female size. For example, Pérez-Camacho et al. (2015) showed that in a Spanish

357 population of a forest raptor, the northern goshawk Accipiter gentilis, L., small breeding males

358 had more fledglings than larger males, while the reproductive success of females remained

359 unaffected. The net result suggests an intensified sex role differentiation and therefore RSD.

\section{Territoriality and territory size}

361 RSD is positively associated with increasing degree of territoriality in diurnal raptor species of

362 the New World and the Western Palearctic. This finding extends previous evidence, derived

363 from only a few species, that raptor RSD may have evolved by sexual selection through

364 competition among males for a territory (Widén 1984), or among females for the best males or

365 territories (Sergio et al. 2007; McDonald et al. 2005; Pérez-Camacho et al. 2015). Our study

366 provides modern, large-scale confirmation of the observations, first reported nearly four decades 
367 ago, that colonial and semi-colonial species show lower RSD than territorial species (Snyder and

368 Wiley 1976; Walter 1979), and that RSD increases with increasing size of the territory defended

369 (Walter 1979). Those works failed to propose mechanisms to explain how intra-sexual

370 competition for a territory may have influenced the body size of both sexes. Our results inspire

371 the following proposal for how territoriality and territory size may have exerted selective

372 pressures on males, females or both, leading to increased RSD. As "owners" of the nesting

373 territory, males are responsible for defending it and defining its boundaries against other males

374 (Newton 1979; Olsen and Olsen 1987). Disputes between males for ownership and delimitation

375 of the territories are solved by aerial displays and, ultimately, air fights (Cade 1960; Andersson

376 and Norberg 1981; Widén 1984). In species equipped with harmful weapons like talons, agility is

377 more important than size and strength, where agility is defined as manoeuvrability and the ability

378 to ascend rapidly in order to take up an advantageous position above the opponent (Widén 1984).

379 Consequently, smaller and more agile males should outcompete their congeners due to their

380 higher probability of obtaining a territory to breed and leave offspring.

381 Females, occupy and defend from other females a small portion of the nesting territory near the

382 nest; this "territory" is usually limited to the area where the male brings food and transfers it to

383 the female (Olsen and Olsen 1987). We suggest that these disputes between females, which take

384 place near the ground over smaller areas than the entire nesting territory, are resolved through

385 aggressive displays with or without physical contact. In this case, size and strength should be

386 most important for intimidating and expelling competitors from the feeding area, which would

387 favour larger females. Studies for three diurnal raptor species (Northern goshawk and Black kite

388 in Spain and Brown falcon in Australia) have shown that larger females are more likely to be

389 recruited as breeders than smaller ones (McDonald et al. 2005; Sergio et al. 2007; Pérez- 
390 Camacho et al. 2015). Contrary to what is observed in males, larger and stronger females should

391 have a competitive advantage in acquiring territories, increasing their chances of breeding. In

392 this way, selective pressures from territoriality in both males and females may increase RSD.

393 Our finding that raptor RSD increases with increasing size of the territory defended echoes the

394 results of one study conducted nearly four decades ago by Walter (1979) in Eleonora's Falcon

395 Falco eleonorae, Gené. We propose that for territorial species similar in size, males and females

396 of species defending smaller nesting territories experience weaker competitive pressures to breed

397 than species defending larger nesting territories. The former species should have access to a

398 greater density of suitable breeding sites where they experience weaker selective pressures, so

399 they should show lower RSD than species defending larger nesting territories. Another non-

400 exclusive reason for increasing RSD with increasing territory size would select for small male

401 (provider of prey) body size due to energetic costs, i.e., longer movements during foraging in the 402 larger territories.

403 Based on our present findings, we can hypothesise that the selective pressures induced by all the

404 predictors analysed here favour a strong reduction in male size, which would explain the

405 evolution of RSD in raptors. These results agree with Krüger's (2005) who found strong support

406 for male reduction and little support for female enlargement in a comparative study comprising

407510 species of diurnal raptors and owls. However, territoriality can also promote an increase in

408 female size, as evidenced by previous studies (McDonald et al. 2005; Sergio et al. 2007; Pérez-

409 Camacho et al. 2015) and by our results. We propose that the evolution of RSD in diurnal raptors

410 reflects primarily a strong reduction in male size, together with a possible weaker enlargement of

411 females in some species. 
412 In conclusion, this study shows how the hunting strategy of raptors (prey agility and hunting 413 habitat) may have influenced their RSD: the greater the prey agility and structural complexity of

414 the hunting habitat in the breeding season, the greater the RSD. A substantial proportion of the

415 well-established influence of prey agility (or prey type) on raptor RSD may also be linked to 416 evolutionary pressures related to territoriality and territory size. In sum, our results show how

417 intricate relationships amongst both eltonian (trophic) and grinnellian (spatial) aspects of diurnal

418 raptors' niches may have acted as selective pressures leading to the evolution of RSD. The 419 substantial amount of variation in raptor RSD explained by prey agility, habitat complexity and 420 territoriality advices future studies to consider these factors.

\section{Acknowledgements}

423 We are indebted to Keith Bildstein for providing us with body mass data from the Striated

424 Caracara. We are grateful to Travis Rosenberry from The Peregrine Fund library for providing 425 copies of several publications during the review process and to José Manuel Fernández-Pereira 426 for helping with this project. We thank Mónica Díaz-Otero, Armando Chapin Rodríguez, Geir A. 427 Sonerud for valuable comments on the manuscript.

428 Funding - This work was supported by funds from CICYT projects of the Spanish Ministerio de 429 Educación y Ciencia (CGL2007-60533/BOS, CGL2010-18312/BOS) and Ministerio de 430 Economía y Competitividad (CGL2014-533308-P), projects of the Alcalá University 431 (CCG2014/BIO-002), and the REMEDINAL network (S-0505/AMB/0335, S-2009/AMB/1783 432 and S-2013/MAE/2719). SMH and GGS were supported, respectively, by an FPI fellowship 433 (BES-2008-006630) and an FPU fellowship (AP2006-00891) from the Ministerio de Educación 434 y Ciencia. IMC received support from the Integrated Program of IC\&DT (No. 

1/SAESCTN/ALENT-07-0224-FEDER-001755) and from the Fonds de Recherches du Québec -

436 Nature et Technologies (FQRNT) programme, Projet de Recherche en Équipe. There is no 437 conflict of interest.

438 Authors' contributions - LP, SM, SR and GG conceived the ideas and designed methodology. 439 SM and LP collected the data. IM and SM analysed the data. LP, SM and IM led the writing of 440 the manuscript. All authors contributed critically to the drafts and gave final approval for 441 publication.

442 Conflicts of interest - The authors declare that they have no conflict of interest.

\section{References}

445 Amadon, D. 1959. The significance of sexual differences in size among birds. — Proc. Am. $446 \quad$ Philos. Soc. 103: 531-536.

447 Andersson, M. and Norberg, R. 1981. Evolution of reversed sexual size dimorphism and role 448 partitioning among predatory birds, with a size scaling of flight performance. — Biol. J. Linn. $449 \quad$ Soc. $15: 105-130$.

450 Belsley, D. A. 1991. Conditioning diagnostics: Collinearity and weak data in regression. $451 \quad$ Wiley.

452 Brown, J. L. 1964. The evolution of diversity in avian territorial systems. — Wilson Bull. 76: 453 160-169.

454 Cade, T. 1960. Ecology of the Peregrine and Gyrfalcon populations in Alaska. - University of 455 California publications in zoology 63: 151-290.

456 del Hoyo, J. et al. 1994. Handbook of the birds of the world. - Lynx Edicions.

457 Dial, K. P. et al. 2008. Allometry of behavior. — Trends Ecol. Evol. 23: 394-401. 
458 Dutilleul, P. et al. 1993. Modifying the $\mathrm{t}$ test for assessing the correlation between two spatial 459 processes. - Biometrics 305-314.

460 Ferguson-Lees, J. and Christie, D. A. 2001. Raptors of the World. - Christopher Helm.

461 Freckleton, R. P. et al. 2002. Phylogenetic analysis and comparative data: A test and review of 462 evidence. - Am. Nat. 160: 712-726.

463 Friedman, N. R. and Remeš, V. 2016. Global geographic patterns of sexual size dimorphism in 464 birds: support for a latitudinal trend? - Ecography 39: 17-25. doi: 10.1111/ecog.01531

465 Garland, Jr, T. et al. 1993. Phylogenetic analysis of covariance by computer simulation. - Syst. 466 Biol. 42: 265-292.

467 Hadfield, J. D. 2010. MCMC methods for multi-response generalized linear mixed models: the 468 MCMCglmm R package. J. Stat. Softw. 33: 1-22.

469 Hadfield, J. D. and Nakagawa, S. 2010. General quantitative genetic methods for comparative 470 biology: phylogenies, taxonomies and multi-trait models for continuous and categorical 471 characters. — J. Evol. Biol. 23: 494-508. doi:10.1111/j.1420-9101.2009.01915.x

472 Hakkarainen, H. et al. 1996. A test of male mating and hunting success in the kestrel: The 473 advantages of smallness? — Behav. Ecol. Sociobiol. 39: 375-380.

474 Hill, N. P. 1944. Sexual dimorphism in the Falconiformes. - Auk 61: 228-234.

475 Jehl Jr, J. R. and Murray Jr, B. G. 1986. The evolution of normal and reverse sexual size 476 dimorphism in shorebirds and other birds. - Curr. Ornithol. 3: 1-86.

477 Jetz, W. et al. 2012. The global diversity of birds in space and time. — Nature 491: 444-448.

478 Krüger, O. 2005. The evolution of reversed sexual size dimorphism in hawks, falcons and owls: 479 A comparative study. — Evol. Ecol. 19: 467-486. 
480

481

482

483

484

485

486

487

488

489

490

491

492

493

494

495

496

497

498

499

500

Martínez-Hesterkamp, S. et al. 2018in press. Territoriality in diurnal raptors: relative roles of recent evolution, diet and nest site. — Biol. J. Linnean Soc. 124: 126-137.

Massemin, S. et al. 2000. Reversed sexual size dimorphism in raptors: evaluation of the hypotheses in kestrels breeding in a temporally changing environment. — Oecologia 124: 2632.

McDonald, P. G. et al. 2005. Selection on body size in a raptor with pronounced reversed sexual size dimorphism: are bigger females better? — Behav. Ecol. 16: 48-56.

Micallef, L. and Rodgers, P. 2014. eulerAPE: Drawing Area-proportional 3-Venn Diagrams Using Ellipses. — PLoS ONE 9: e101717. doi:10.1371/journal.pone.0101717.

Newton, I. 1979. Population ecology of raptors. — T \& A D Poyser.

Newton, I. 2003. Population regulation in birds: is there anything new since David Lack? Avian science 3: 75-84.

Newton, I. and Marquiss, M. 1984. Seasonal Trend in the Breeding Performance of

Sparrowhawks. — J. Anim. Ecol. 53: 809-829.

Nilsson, I.N. et al. 1982. Diet choice, resource depression, and the regular nest spacing of birds of prey. — Biol. J. Linnean Soc. 18: 1-9.

Olsen, P. D. and Olsen, J. 1987. Sexual size dimorphism in raptors: intrasexual competition in the larger sex for a scarce breeding resource, the smaller sex. — Emu 87: 59-62.

Orme, D. et al. 2013. The caper package: comparative analysis of phylogenetics and evolution in R. R package version 0.5.2.

Pagel, M. 1999. Inferring the historical patterns of biological evolution. — Nature 401: 877-884. 
501 Palmqvist, P. et al. 1996. Relación entre peso corporal, tamaño del territorio, tamaño de puesta y 502 tiempo de desarrollo en algunas rapaces del Paleártico Occidental. — Bol. R. Soc. Esp. Hist.

$503 \quad$ Nat., Secc. Biol. 92: 47-54.

504 Paradis, E. et al. 2004. APE: analyses of phylogenetics and evolution in R language. 505 Bioinformatics 20: 289-290.

506 Paton, P. W. C. et al. 1994. A phylogenetic approach to reversed size dimorphism in diurnal 507 raptors. - Oikos 71: 492-498.

508 Patterson, I. J. 1980. Territorial behaviour and the limitation of population density. — Ardea 68: $509 \quad 53-62$.

510 Pérez-Camacho, L. et al. 2015. Higher reproductive success of small males and greater 511 recruitment of large females may explain strong reversed sexual dimorphism (RSD) in the 512 northern goshawk. — Oecologia 177: 379-387.

513 R Development Core Team 2009. R: a language and environment for statistical computing. R $514 \quad$ Foundation for Statistical Computing.

515 Rangel, T. F. et al. 2010. SAM: a comprehensive application for spatial analysis in 516 macroecology. - Ecography 33: 46-50.

517 Rebollo, S. et al. 2017. Spatial relationships and mechanisms of coexistence between dominant 518 and subordinate top predators. — J Avian Biol, 48: 1226-1237. doi:10.1111/jav.01337

519 Reynolds, R. T. 1972. Sexual dimorphism in accipiter hawks: a new hypothesis. — Condor 74: $520 \quad 191-197$.

521 Revell, L. J. 2012. phytools: an R package for phylogenetic comparative biology (and other 522 things). Methods Ecol. Evol. 3: 217-223.

523 Schoener, T. W. 1968. Sizes of feeding territories among birds. - Ecology 49: 123-141. 
524 Sergio, F. et al. 2007. Despotic, sequential settlement on territory by a migratory raptor. $525 \quad$ Behav. Ecol. 18: 811-821.

526 Slagsvold, T. and Sonerud, G. A. 2007. Prey size and ingestion rate in raptors: importance for 527 sex roles and reversed sexual size dimorphism. - J. Avian Biol. 38: 650-661.

528 Slagsvold, T. et al. 2010. Prey handling in raptors in relation to their morphology and feeding 529 niches. — J. Avian Biol. 41: 488-497. doi:10.1111/j.1600-048X.2010.05081.X

530 Snyder, N. F. and Wiley, J. W. 1976. Sexual size dimorphism in hawks and owls of North 531 America. - Ornithol. Monogr. 20: 1-95.

532 Sonerud, G. A. et al. 2013. Size-biased allocation of prey from male to offspring via female: 533 family conflicts, prey selection, and evolution of sexual size dimorphism in raptors. 534 Oecologia 172: 93-107.

535 Sonerud, G. A. et al. 2014a. Evolution of parental roles in provisioning birds: diet determines 536 role asymmetry in raptors. - Behav. Ecol. 25: 762-772.

537 Sonerud, G. A. et al. 2014b. Evolution of parental roles in raptors: prey type determines role 538 asymmetry in the Eurasian kestrel. — Anim. Behav. 96: 31-38.

539 Storer, R. W. 1966. Sexual dimorphism and food habits in three North American accipiters. $540 \quad$ Auk 83: 423-436.

541 Sutherland, W. J. et al. 2013. Identification of 100 fundamental ecological questions. — J. Ecol. $542 \quad 101: 58-67$.

543 Székely, T. et al. 2007. Sexual size dimorphism in birds. — In: Fairbairn, D. et al. (eds), Sex, 544 size and gender roles. Evolutionary studies of sexual size dimorphism. Oxford University 545 Press, pp. 27-37. 
546 Székely, T. et al. 2000. Sexual size dimorphism in shorebirds, gulls, and alcids: the influence of 547 sexual and natural selection. - Evolution 54: 1404-1413.

548 Temeles, E. J. 1985. Sexual size dimorphism of bird-eating hawks: the effect of prey

549 vulnerability. - Am. Nat. 125: 485-499.

550 Tornberg, R. et al. 2014. Diet shift induced rapid evolution of size and function in a predatory 551 bird. — Oecologia 176: 781-788.

552 Tornberg, R. et al. 1999. Changes in diet and morphology of Finnish goshawks from 1960s to 553 1990s. - Oecologia 121: 369-376.

554 Walter, H. 1979. Eleonora's Falcon: adaptations to prey and habitat in a social raptor. $555 \quad$ University of Chicago Press.

556 Wheeler, P. and Greenwood, P. J. 1983. The evolution of reversed sexual dimorphism in birds of 557 prey. - Oikos 40: 145-149.

558 Widén, P. 1984. Reversed sexual size dimorphism in birds of prey: revival of an old hypothesis.

559 - Oikos 43: 259-263.

560 Ydenberg, R. C. and Forbes, L. S. 1991. The survival-reproduction selection equilibrium and 561 reversed size dimorphism in raptors. — Oikos 60: 115-120.

562

563 Supplementary material (Appendix XXXXX (insert manuscript number) at LÄNK). Appendix $564 \quad 1-4$. 


\section{Tables}

566 Table 1. Summary of the hypotheses proposed here to explain RSD variation in diurnal raptors. The selective pressures, responses, competitive

567 advantages and outcomes derived from each hypothesis are outlined.

\begin{tabular}{|c|c|c|c|c|}
\hline Hypothesis & Selective pressure & Response & Competitive advantage & Outcome for RSD \\
\hline Prey agility & $\begin{array}{l}\text { Agility of the main prey during } \\
\text { breeding season }\end{array}$ & Increased male agility & $\begin{array}{l}\text { Hunting efficiency during } \\
\text { breeding season }\end{array}$ & \\
\hline Hunting habitat structure & $\begin{array}{l}\text { Structural complexity of the hunting } \\
\text { habitat during breeding season }\end{array}$ & Increased male agility & $\begin{array}{l}\text { Hunting efficiency during } \\
\text { breeding season }\end{array}$ & \\
\hline \multirow{2}{*}{$\begin{array}{l}\text { Territoriality or } \\
\text { Territory size }\end{array}$} & \multirow{2}{*}{$\begin{array}{l}\text { Territoriality during breeding season } \\
\text { or } \\
\text { Nesting territory size }\end{array}$} & $\begin{array}{l}\text { Increased female strength and } \\
\text { volume }\end{array}$ & $\begin{array}{l}\text { Female competition for male and } \\
\text { his territory }\end{array}$ & \\
\hline & & Increased male agility & $\begin{array}{l}\text { Male competition for territory via } \\
\text { acrobatic flight displays }\end{array}$ & \\
\hline
\end{tabular}


569 Table 2. Multiple regression models of diurnal raptor RSD in the New World and Western Palearctic.

\begin{tabular}{|c|c|c|c|c|c|c|c|c|c|c|c|c|c|c|c|c|}
\hline \multirow[b]{2}{*}{ Model } & \multicolumn{3}{|c|}{ Prey agility } & \multicolumn{3}{|c|}{ Hunting habitat } & \multicolumn{3}{|c|}{ Territoriality } & \multicolumn{3}{|c|}{ Territory size index } & \multirow[b]{2}{*}{$\lambda$} & \multirow[b]{2}{*}{$\delta$} & \multirow[b]{2}{*}{$R_{a d j}^{2}$} & \multirow[b]{2}{*}{$C N$} \\
\hline & $\beta_{2}$ & $t$ & $P \leq$ & $\beta_{1}$ & $t$ & $P \leq$ & $\beta_{3}$ & $t$ & $P \leq$ & $\beta_{3}$ & $t$ & $P \leq$ & & & & \\
\hline OLS (75 sp.) & 0.591 & 6.482 & $<.001$ & 0.254 & 3.013 & 0.004 & 0.103 & 1.112 & 0.27 & & & & 0.000 & 1.000 & 0.500 & 1.662 \\
\hline PGLS (75 sp.) & 0.574 & 5.877 & 0.000 & 0.250 & 2.838 & 0.006 & 0.133 & 1.450 & 0.152 & & & & 0.950 & 14.407 & 0.462 & \\
\hline OLS (36 sp.) & 0.429 & 2.619 & 0.014 & 0.353 & 2.578 & 0.015 & & & & 0.266 & 1.591 & 0.122 & 0.000 & 1.000 & 0.398 & 2.027 \\
\hline PGLS (36 sp.) & 0.433 & 2.626 & 0.013 & 0.349 & 2.524 & 0.017 & & & & 0.241 & 1.430 & 0.162 & 0.890 & 15.981 & 0.365 & \\
\hline
\end{tabular}

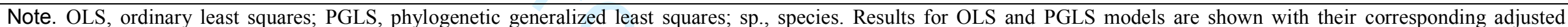

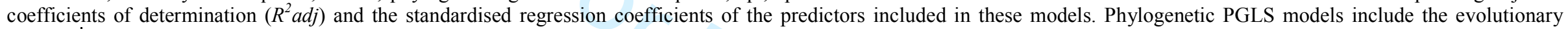

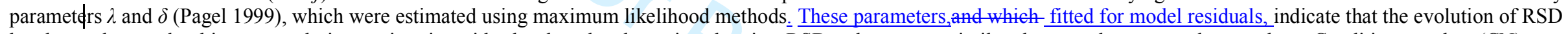

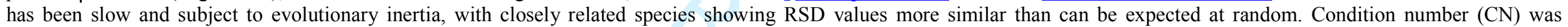
calculated for OLS models; values smaller than five indicate that collinearity among predictors does not affect regression coefficients (Belsley 1991). 


\section{Figures}

571 Figure 1. Relationship of RSD in New World and Western Palearctic raptors (based on body 572 mass) to (a) agility of the main prey; (b) hunting habitat in breeding season, scored on a scale

573 from open habitat to interior of closed forest; and (c) nesting territorial behaviour. Error bars 574 indicate 1 S.E and number above bars the number of raptor species. Statistical significance as 575 measured by a phylogenetic ANOVA (Garland et al. 1993) was found for agility of the main 576 prey $(\mathrm{F}=11.564 ; \mathrm{p}=0.001)$, hunting habitat $(\mathrm{F}=7.987 ; \mathrm{p}=0.038)$ and, nesting territoriality $577(\mathrm{~F}=7.239 ; \mathrm{p}=0.015)$. For the equivalent figure showing RSD based on cubed wing length, 578 see Supplementary material Appendix 3, Fig. A1.

Figure 2. Relationship of RSD in New World and Western Palearctic raptors (based on body mass) to territory size index. This index was calculated as the average nearest-neighbour inter-nest distance in the population $/ \log _{10}$ (mean male body mass). For the equivalent figure showing RSD based on cubed wing length, see Supplementary material Appendix 3, Fig. A2.

Figure 3. Euler diagrams of 3-way partial regressions illustrating shared and independent relationships among prey agility (blue), habitat structure (green) and territoriality or territory size (purple) for explaining different amounts of variation in RSD across raptor species in New World and Western Palearctic raptors for (a) all species $(n=75)$ and (b) the subset of

589 territorial species $(\mathrm{n}=36)$. Ellipse size is proportional to the amount of variation in RSD 590 explained by each predictor. Note that in panel (b), the grey-shaded area indicates a negative 591 value resulting from interactions among predictor variables. See Supplementary material 592 Appendix 3, Table A1 for details on partial regression results. 
(a)

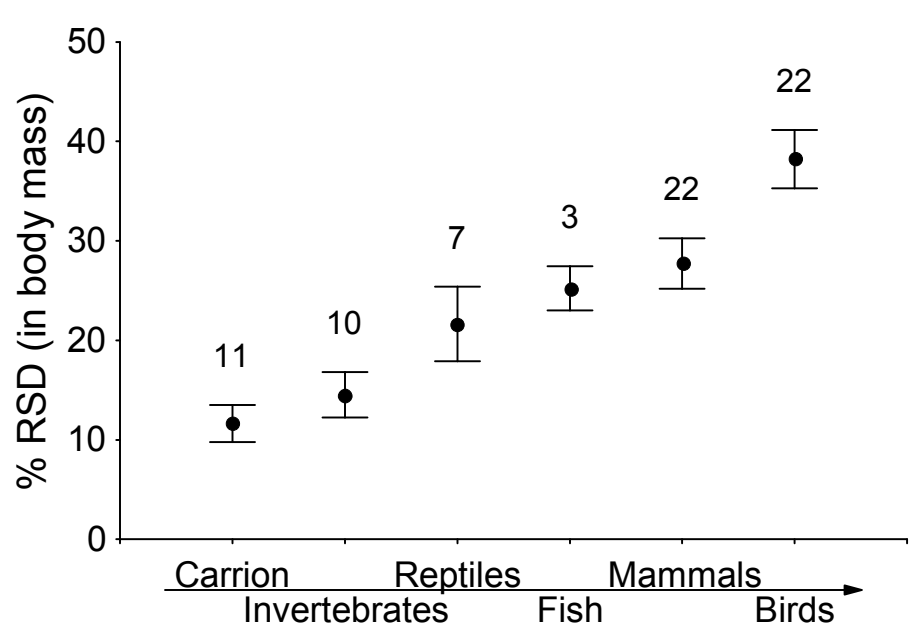

(b)

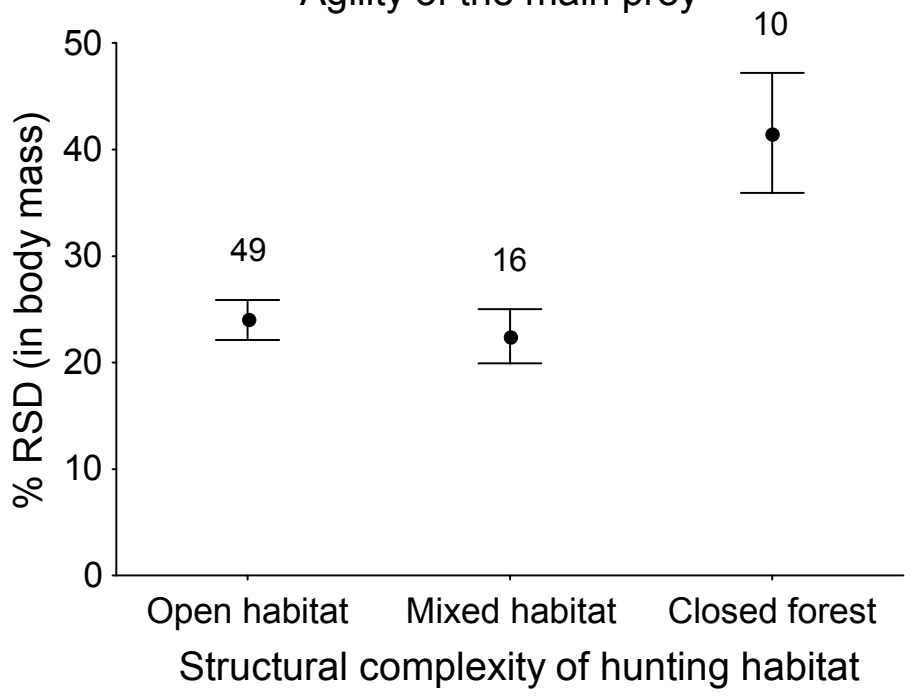

(c)

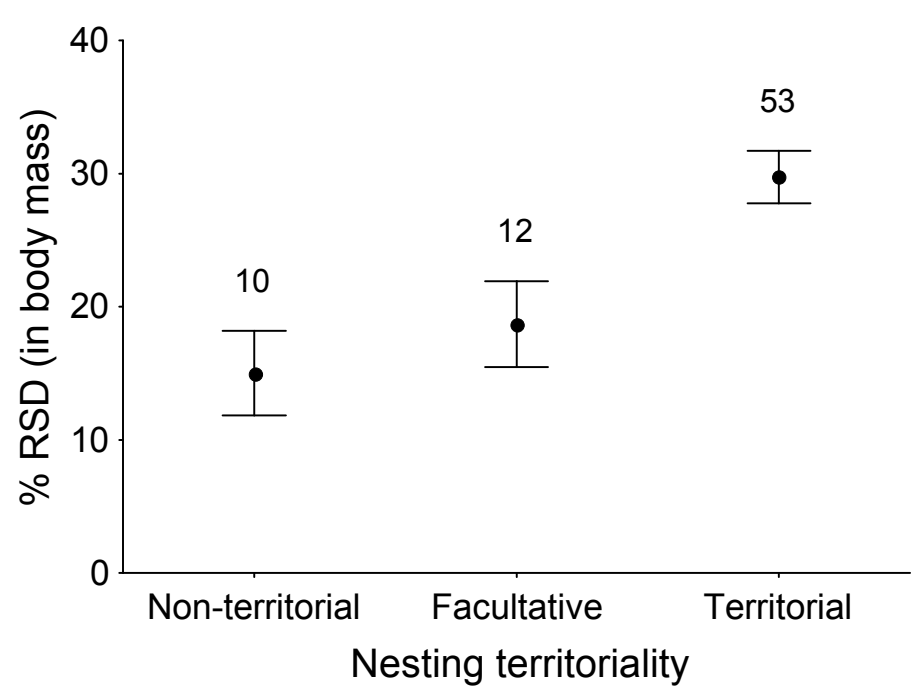




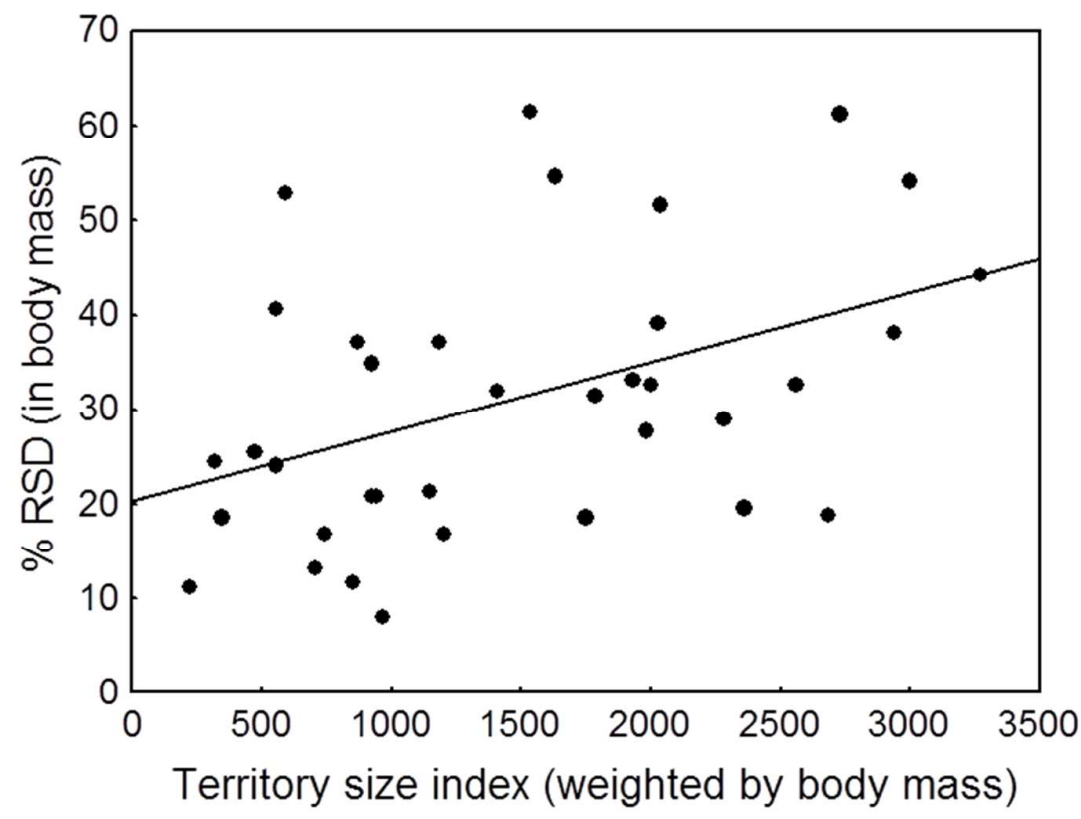

595

$596 \quad$ Figure 2 


\section{A) 75 species}

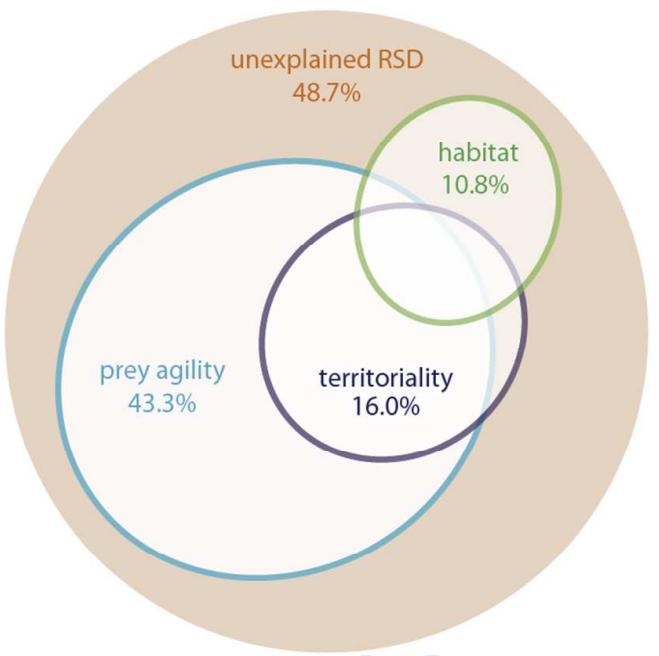

597

$598 \quad$ Figure 3

\section{B) 36 species}

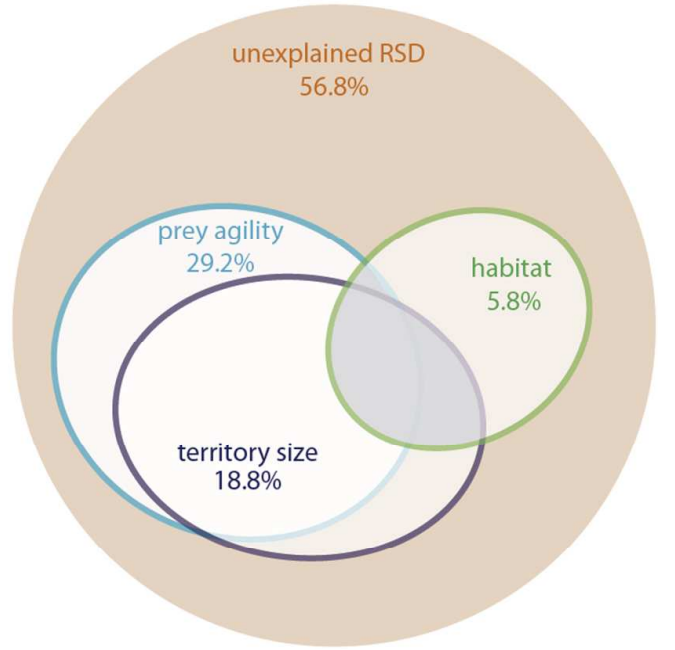




\section{Supplementary material for "Structural complexity of hunting habitat and} territoriality increase the reversed sexual dimorphism in diurnal raptors".

Appendix 1. Complete data set (Table A1) and lists of data sources used in this work.

Table A1. Complete data set of the respond and predictor variables for the 75 species of diurnal raptors used in this work. Territory size index was calculated only for territorial species for which we had data on distances to nearest neighbour nests $(n=36)$. Reversed sexual dimorphism was calculated using body mass and cubed wing length $(\mathrm{RSD}=100 \times[($ female body measure - male body measure $) /(0.5 \times($ female measure + male measure $))]$. Hunting habitat: $1=$ open habitat; $2=$ semi-open habitat; 3 = closed habitat. Prey agility (i.e. species' main prey): $1=$ carrion; $2=$ invertebrates; 3 = reptiles and amphibians; $4=$ fish; $5=$ mammals; $6=$ birds. Territorial behaviour: $0=$ non-territorial; 1 = facultative; 2 = territorial. Territory size index $=$ mean inter-nest distance $/$ $\log _{10}$ (mid-range of male body mass). $\mathrm{ND}=$ Not Determined.

\begin{tabular}{|c|c|c|c|c|c|c|c|}
\hline Family & Species & $\begin{array}{l}\text { RSD } \\
\text { (body } \\
\text { mass) }\end{array}$ & $\begin{array}{c}\text { RSD } \\
\text { (cubed } \\
\text { wing } \\
\text { length) }\end{array}$ & $\begin{array}{c}\text { Hunting } \\
\text { habitat }\end{array}$ & $\begin{array}{c}\text { Prey } \\
\text { agility }\end{array}$ & $\begin{array}{c}\text { Territorial } \\
\text { behavior }\end{array}$ & $\begin{array}{l}\text { Territory } \\
\text { size index }\end{array}$ \\
\hline Falconidae & Micrastur semitorquatus & 33.6 & 14.2 & 3 & 5 & 0 & - \\
\hline Falconidae & Herpetotheres cachinnans & 12.9 & 1.1 & 2 & 3 & 2 & ND \\
\hline Falconidae & Caracara plancus & 13.3 & 4.1 & 1 & 1 & 2 & ND \\
\hline Falconidae & Ibycter americanus & 20.7 & 6.1 & 3 & 2 & 2 & ND \\
\hline Falconidae & Milvago chimango & 3.7 & 15.2 & 1 & 1 & 0 & - \\
\hline Falconidae & Phalcoboenus australis & 10.5 & 8.5 & 1 & 1 & 1 & - \\
\hline Falconidae & Falco deiroleucus & 54.3 & 40.0 & 1 & 6 & 2 & 2994.7 \\
\hline Falconidae & Falco rufigularis & 48.3 & 49.6 & 1 & 6 & 2 & ND \\
\hline Falconidae & Falco vespertinus & 7.0 & 10.5 & 1 & 2 & 1 & - \\
\hline Falconidae & Falco columbarius & 20.9 & 27.1 & 1 & 6 & 2 & 936.1 \\
\hline Falconidae & Falco sparverius & 11.0 & 9.9 & 1 & 2 & 1 & - \\
\hline Falconidae & Falco eleonorae & 10.3 & 18.7 & 1 & 6 & 0 & - \\
\hline Falconidae & Falco subbuteo & 28.0 & 12.0 & 1 & 6 & 2 & 1982.8 \\
\hline Falconidae & Falco tinnunculus & 18.7 & 15.3 & 1 & 5 & 1 & - \\
\hline Falconidae & Falco naumanni & 27.6 & 5.0 & 1 & 2 & 0 & - \\
\hline Falconidae & Falco mexicanus & 37.2 & 32.4 & 1 & 5 & 2 & 865.3 \\
\hline Falconidae & Falco pelegrinoides & 54.8 & 37.1 & 1 & 6 & 2 & 1630.0 \\
\hline Falconidae & Falco peregrinus & 44.3 & 38.2 & 1 & 6 & 2 & 3264.3 \\
\hline Falconidae & Falco rusticolus & 38.3 & 19.4 & 1 & 6 & 2 & 2932.9 \\
\hline Falconidae & Falco cherrug & 32.8 & 35.1 & 1 & 5 & 2 & 1995.8 \\
\hline Falconidae & Falco biarmicus & 37.0 & 31.9 & 1 & 6 & 2 & ND \\
\hline
\end{tabular}


Table A1. Continuation

\begin{tabular}{|c|c|c|c|c|c|c|c|}
\hline Family & Species & $\begin{array}{l}\text { RSD } \\
\text { (body } \\
\text { mass) }\end{array}$ & $\begin{array}{c}\text { RSD } \\
\text { (cubed } \\
\text { wing } \\
\text { length) }\end{array}$ & $\begin{array}{c}\text { Hunting } \\
\text { habitat }\end{array}$ & $\begin{array}{c}\text { Prey } \\
\text { agility }\end{array}$ & $\begin{array}{c}\text { Territorial } \\
\text { behavior }\end{array}$ & $\begin{array}{l}\text { Territory } \\
\text { size index }\end{array}$ \\
\hline Cathartidae & Coragyps atratus & 8.8 & 0.1 & 1 & 1 & 0 & - \\
\hline Cathartidae & Cathartes aura & 13.5 & 5.0 & 1 & 1 & 0 & - \\
\hline Pandionidae & Pandion haliaetus & 25.0 & 13.5 & 1 & 4 & 1 & - \\
\hline Accipitridae & Elanus leucurus & 11.8 & 4.4 & 1 & 5 & 1 & - \\
\hline Accipitridae & Elanus caeruleus & 17.0 & 7.7 & 1 & 5 & 2 & 1200.1 \\
\hline Accipitridae & Pernis apivorus & 8.0 & 2.9 & 2 & 2 & 2 & 963.6 \\
\hline Accipitridae & Elanoides forficatus & 7.6 & 10.9 & 2 & 2 & 0 & - \\
\hline Accipitridae & Gypaetus barbatus & 6.7 & 1.0 & 1 & 1 & 2 & ND \\
\hline Accipitridae & Neophron percnopterus & 15.4 & 11.8 & 1 & 1 & 2 & ND \\
\hline Accipitridae & Circaetus gallicus & 11.8 & 7.1 & 1 & 3 & 2 & 842.7 \\
\hline Accipitridae & Aegypius monachus & 7.8 & 16.3 & 1 & 1 & 1 & - \\
\hline Accipitridae & Gyps fulvus & 6.4 & 13.3 & 1 & 1 & 0 & - \\
\hline Accipitridae & Harpia harpyja & 61.4 & 22.0 & 3 & 5 & 2 & 2726.4 \\
\hline Accipitridae & Spizaetus ornatus & 36.7 & 22.6 & 3 & 6 & 2 & ND \\
\hline Accipitridae & Aquila pomarina & 37.3 & 9.5 & 1 & 5 & 2 & 1177.1 \\
\hline Accipitridae & Aquila clanga & 17.7 & 16.1 & 1 & 5 & 2 & ND \\
\hline Accipitridae & Hieraaetus pennatus & 31.6 & 27.8 & 1 & 6 & 2 & 1780.0 \\
\hline Accipitridae & Aquila chrysaetos & 32.8 & 23.0 & 1 & 5 & 2 & 2555.5 \\
\hline Accipitridae & Aquila fasciatus & 19.0 & 11.2 & 1 & 6 & 2 & 2679.1 \\
\hline Accipitridae & Aquila nipalensis & 18.8 & 23.8 & 1 & 5 & 2 & 1745.4 \\
\hline Accipitridae & Aquila adalberti & 19.7 & 20.0 & 2 & 5 & 2 & 2353.7 \\
\hline Accipitridae & Aquila heliaca & 39.2 & 16.0 & 1 & 5 & 2 & 2024.6 \\
\hline Accipitridae & Accipiter striatus & 51.9 & 55.8 & 3 & 6 & 2 & 2034.8 \\
\hline Accipitridae & Accipiter nisus & 53.1 & 48.7 & 3 & 6 & 2 & 587.0 \\
\hline Accipitridae & Accipiter gentilis & 32.0 & 31.1 & 2 & 6 & 2 & 1404.8 \\
\hline Accipitridae & Accipiter cooperii & 61.6 & 44.2 & 3 & 6 & 2 & 1525.7 \\
\hline Accipitridae & Accipiter bicolor & 57.4 & 55.7 & 3 & 6 & 2 & ND \\
\hline Accipitridae & Circus aeruginosus & 22.2 & 14.6 & 1 & 6 & 1 & - \\
\hline Accipitridae & Circus cinereus & 38.1 & 32.4 & 1 & 6 & 1 & - \\
\hline Accipitridae & Circus cyaneus & 40.9 & 27.0 & 1 & 5 & 1 & - \\
\hline Accipitridae & Harpagus bidentatus & 13.4 & 16.6 & 3 & 2 & 2 & 700.8 \\
\hline Accipitridae & Milvus milvus & 25.7 & 9.9 & 1 & 1 & 2 & 472.3 \\
\hline Accipitridae & Milvus migrans & 16.3 & 10.1 & 1 & 1 & 1 & - \\
\hline Accipitridae & Haliaeetus albicilla & 29.2 & 28.2 & 1 & 4 & 2 & 2277.9 \\
\hline Accipitridae & Haliaeetus leucocephalus & 21.5 & 23.6 & 1 & 4 & 2 & 1144.6 \\
\hline Accipitridae & Rostrhamus sociabilis & 14.5 & 2.9 & 1 & 2 & 0 & - \\
\hline Accipitridae & Ictinia mississippiensis & 24.0 & 11.9 & 2 & 2 & 0 & - \\
\hline Accipitridae & Ictinia plumbea & 11.4 & 6.1 & 2 & 2 & 2 & 212.0 \\
\hline
\end{tabular}


Table A1. Continuation

\begin{tabular}{llcccccc}
\hline Family & Species & $\begin{array}{c}\text { RSD } \\
\text { (body } \\
\text { mass) }\end{array}$ & $\begin{array}{c}\text { RSD } \\
\text { (cubed } \\
\text { wing } \\
\text { length) }\end{array}$ & $\begin{array}{c}\text { Hunting } \\
\text { habitat }\end{array}$ & $\begin{array}{c}\text { Prey } \\
\text { agility }\end{array}$ & $\begin{array}{c}\text { Territorial } \\
\text { behavior }\end{array}$ & $\begin{array}{c}\text { Territory } \\
\text { size index }\end{array}$ \\
\hline Accipitridae & Buteogallus anthracinus & 40.8 & 14.3 & 2 & 3 & 2 & 551.9 \\
Accipitridae & Parabuteo unicinctus & 25.9 & 22.5 & 1 & 5 & 2 & ND \\
Accipitridae & Buteo magnirostris & 18.8 & 11.7 & 2 & 3 & 2 & 340.9 \\
Accipitridae & Buteo nitidus & 17.5 & 15.2 & 2 & 3 & 2 & ND \\
Accipitridae & Buteo lineatus & 24.1 & 8.8 & 2 & 3 & 2 & 551.1 \\
Accipitridae & Buteo ridgwayi & 25.8 & 28.1 & 3 & 3 & 2 & ND \\
Accipitridae & Buteo platypterus & 24.8 & 22.1 & 2 & 5 & 2 & 316.4 \\
Accipitridae & Buteo jamaicensis & 17.0 & 20.2 & 2 & 5 & 2 & 741.1 \\
Accipitridae & Buteo solitarius & 31.5 & 28.3 & 2 & 6 & 2 & ND \\
Accipitridae & Buteo galapagoensis & 36.3 & 31.5 & 2 & 6 & 2 & ND \\
Accipitridae & Buteo swainsoni & 34.9 & 13.0 & 1 & 5 & 2 & 916.4 \\
Accipitridae & Buteo albonotatus & 33.2 & 30.9 & 2 & 6 & 2 & 1925.7 \\
Accipitridae & Buteo regalis & 15.8 & 5.5 & 1 & 5 & 2 & ND \\
Accipitridae & Buteo lagopus & 21.0 & 18.0 & 1 & 5 & 2 & 914.7 \\
Accipitridae & Buteo rufinus & 36.5 & 19.3 & 1 & 5 & 2 & ND \\
Accipitridae & Buteo buteo & 15.2 & 12.5 & 1 & 5 & 1 & - \\
\hline
\end{tabular}

\section{LISTS OF REFERENCES}

Main data sources for all variables except territory size:

Cramp, S. 1998. The complete Birds of the Western Palearctic on CD-ROM. - Oxford University Press.

del Hoyo, J. et al. 1994. Handbook of the birds of the world. - Lynx Edicions.

Ferguson-Lees, J. and Christie, D. A. 2001. Raptors of the World. - Christopher Helm.

Natureserve 2011. NatureServe Explorer: An online encyclopedia of life [web application]. Version 7.0. Natureserve.

Publications that provided RSD data for some species:

Bollmer, J. L. et al. 2003. Variation in morphology and mating system among island populations of Galapagos Hawks. - Condor 105: 428-438.

Gaby, S. R. P. 1982. Age-specific resource utilization by wintering migrant Turkey Vultures (Cathartes aura) in south Florida. University of Miami. 
Miller, A. H. 1952. Supplementary data on the tropical avifauna of the arid upper Magdalena Valley of Colombia. - Auk 69: 450-457.

Mosher, J. A. and Matray, P. F. 1974. Size dimorphism a factor in energy savings for Broad-winged Hawks. — Auk 91: 325-341.

Woolaver, L. G. et al. 2013. Nestling sex ratio in a critically endangered dimorphic raptor, Ridgway's Hawk (Buteo ridgwayi). — J. Raptor Res. 47: 117-126.

Publications that provided data on territorial behaviour for some species:

Berry, R. B. et al. 2010. Isolation and decline of a population of the Orange-breasted Falcon. - Condor 112: 479-489.

Hengstenberg, D. W. and Vilella, F. J. 2005. Nesting ecology and behavior of Broadwinged Hawks in moist karst forests of Puerto Rico. — J. Raptor Res. 39: 404-416.

Kennedy, P. L. et al. 1995. Breeding biology of the Zone-tailed Hawk at the limit of its distribution. - J. Raptor Res. 29: 110-116.

Panasci, T. A. and Whitacre, D. F. 2002. Roadside Hawk breeding ecology in forest and farming landscapes. — Wilson Bull. 114: 114-121.

Schulze, M. D. and Cordova, J. L. 2000. Behavior, diet, and breeding biology of Doubletoothed Kites at a Guatemalan lowland site. - Condor 102: 113-126.

Publications that provided data on territory size:

Anthony, R. G. 2001. Low productivity of Bald Eagles on Prince of Wales Island, southeast Alaska. — J. Raptor Res. 35: 1-8.

Bakaloudis, D. E. et al. 2005. Nest spacing and breeding performance in Short-toed Eagle Circaetus gailicus in northeast Greece. — Bird Study 52: 330-338.

Baker, A. J. et al. 2000. The Orange-breasted Falcon Falco deiroleucus in Mesoamerica: a vulnerable, disjunct population? — Bird Conserv. Int. 10: 29-40.

Balbontin, J. et al. 2008. Land-use changes may explain the recent range expansion of the Black-shouldered Kite Elanus caeruleus in southern Europe. - Ibis 150: 707-716.

Beissinger, S. R. et al. 1988. Vocalizations, food habits, and nesting biology of the Slender- 
billed Kite with comparisons to the Snail Kite. - Wilson Bull. 100: 604-616.

Bergo, G. 1984. Population size, spacing and age structure of Golden Eagle Aquila chrysaetos (L.) in Hordaland, West Norway. — Nor. J. Ornithol. 7: 106-108.

Bezzel, E. and Fuenfstueck, H.-J. 1994. Brutbiologie und Populationsdynamik des Steinadlers (Aquila chrysaetos) im Werdenfelser Land/Oberbayern. - Acta Ornithoecologica 3: 5-32.

Bielański, W. 2006. Nesting preferences of Common Buzzard Buteo buteo and Goshawk Accipiter gentilis in forest stands of different structure (Niepolomice Forest, Southern Poland). — Biologia 61: 597-603.

Bisson, I. A. et al. 2002. Factors influencing nest-site selection by Spanish Imperial Eagles. — J. Field Ornithol. 73: 298-302.

Bosakowski, T. et al. 1996. Habitat and spatial relationships of nesting Swainson's Hawks (Buteo swainsoni) and Red-tailed Hawks (B. jamaicensis) in northern Utah. - Great Basin Nat. 56: 341-347.

Bosch, J. et al. 2005. Nesting habitat selection of Booted Eagle Hieraaetus pennatus in Central Catalonia. - Ardeola 52: 225-233.

Brambilla, M. et al. 2010. Environmental factors affecting patterns of distribution and cooccurrence of two competing raptor species. - Ibis 152: 310-322.

Brown, A. F. and Stillman, R. A. 1998. The return of the Merlin to the south Pennines. Bird Study 45: 293-301.

Brown, B. T. et al. 1992. Density of nesting Peregrine Falcons in Grand Canyon National Park, Arizona. - Southwest. Nat. 37: 188-193.

Brown, C. J. 1997. Population dynamics of the Bearded Vulture Gypaetus barbatus in southern Africa. - Afr. J. Ecol. 35: 53-63.

Buczek, T. et al. 2007. Legowe ptaki szponiaste Falconiformes Lasow Parczzewskich zmiany liczebnosci i rozmieszczenia w latach 1991-1993 i 2002-2004. — Notatki Ornitol. 48: 217-231.

Caniot, P. 1996. Suivi de la reproduction de l'Aigle Royal Aquila chrysaetos dans le 
departement de l'Ariege de 1992 a 1995. — Alauda 64: 187-194.

Castaño, J. P. 2007. Dinámica poblacional del Águila Imperial Ibérica Aquila adalberti en la provincia de Toledo (1989 - 2006). — Ardeola 54: 309-317.

Castaño, J. P. and Guzman, J. 1995. Aspectos sobre la reproduccion de Aquila adalberti y Aquila chrysaetos en Sierra Morena oriental. — Ardeola 42: 83-89.

Castellanos, A. and Jaramillo, F. 1997. Peregrine Falcon recovery along the west central coast of the Baja California Peninsula, Mexico. - J. Raptor Res. 31: 1-6.

Clouet, M. and Goar, J. 2006. L'Aigle Royal Aquila chrysaetos au sud du Sahara. Alauda 74: 441-446.

Craig, T. H. et al. 1984. Results of a helicopter survey of cliff nesting raptors in a deep canyon in Southern Idaho. - Raptor Res. 18: 20-25.

Cugnasse, J.-M. 1984. Le Faucon Pelerin Falco pelegrinus dans le sud du Massif Central de 1974 a 1983. - Alauda 52: 161-176.

Demerdzhiev, D. A. et al. 2011. Status of the Eastern Imperial Eagle (Aquila heliaca) in the European part of Turkey. - Acta Zool. Bulg. 3: 87-93.

Dombrowski, A. et al. 2000. Gniazdowanie ptaków drapieznych Falconiformes i kruka Corvus corax w krajobrazie rolniczym pod Siedlcami w latach 1978 i 1999. — Notatki Ornitol. 41: 201-212.

Erdman, T. C. et al. 1998. Productivity, population trend, and status of Northern Goshawks, Accipiter gentilis atricapillus, in Northeastern Wisconsin. - Can. Field-Nat. 112: 1727.

Fasce, P. et al. 2011. Long-term breeding demography and density dependence in an increasing population of Golden Eagles Aquila chrysaetos. — Ibis 153: 581-591.

Frenzel, R. 1983. Spacing of nest sites and foraging areas of Bald Eagles. - In: Anthony, R. G. et al. (eds), Proceedings of a workshop on habitat management for nesting and roosting Bald Eagles in the Western United States.

Gainzarain, J. A. et al. 2000. Breeding density, habitat selection and reproductive rates of the Peregrine Falcon Falco peregrinus in Alava (northern Spain). — Bird Study 47: 
225-231.

Garland, T. et al. 1993. Phylogenetic analysis of covariance by computer simulation. Syst. Biol. 42: 265-292.

Gavashelishvili, A. and McGrady, M. J. 2006. Breeding site selection by Bearded Vulture (Gypaetus barbatus) and Eurasian Griffon (Gyps fulvus) in the Caucasus. - Anim. Conserv. 9: 159-170.

Gil-Sanchez, J. M. et al. 2004. A nine-year study of successful breeding in a Bonelli's Eagle population in southeast Spain: a basis for conservation. — Biol. Conserv. 118: 685-694.

Grant, C. V. et al. 1991. Raptor population-dynamics in Utah Uinta Basin: the importance of food resource. - Southwest. Nat. 36: 265-280.

Grubb, T. G. 1995. Food-habits of Bald Eagles breeding in the Arizona desert. - Wilson Bull. 107: 258-274.

Hengstenberg, D. W. and Vilella, F. J. 2005. Nesting ecology and behavior of Broadwinged Hawks in moist karst forests of Puerto Rico. — J. Raptor Res. 39: 404-416.

Hobbs, R. J. et al. 2006. Breeding biology and nest-site selection of Red-tailed Hawks in an altered desert grassland. - J. Raptor Res. 40: 38-45.

Horne, G. and Fielding, A. H. 2002. Recovery of the Peregrine Falcon Falco peregrinus in Cumbria, UK, 1966-99. — Bird Study 49: 229-236.

Jenkins, A. R. and van Zyl, A. J. 2005. Conservation status and community structure of cliff-nesting raptors and ravens on the Cape Peninsula, South Africa. — Ostrich 76: 175184.

Jordano, P. 1981. Relaciones interespecíficas y coexistencia entre el Águila Real (Aquila chrysaetos) y el Águila Perdicera (Hieraaetus fasciatus) en Sierra Morena Central. Ardeola 28: 67-88.

Karyakin, I. and Nikolenko, E. 2009. Peregrine Falcon in the Altai-Sayan Region, Russia. - Raptors Conserv. 16: 96-128.

Karyakin, I. V. and al, e. 2010. Golden Eagle in the Altai-Sayan Region, Russia. - Raptors Conserv. 18: 82-152. 
Karyakin, I. V. et al. 2011. Eagles of the Aral-Caspian Region, Kazakhstan. — Raptors Conserv. 22: 92-152.

Karyakin, I. V. et al. 2010a. Saker Falcon in the Karatau Mountains, Kazakhstan. Raptors Conserv. 19: 152-163.

Karyakin, I. V. and Nikolenko, E. G. 2008. Monitoring results on the Saker Falcon population in the Altai-Sayan Region in 2008, Russia. - Raptors Conserv. 14: 63-84.

Karyakin, I. V. and Nikolenko, E. G. 2010. The Imperial Eagle in the Republic of Khakassia and Krasnoyarsk Kray, Russia. — Raptors Conserv. 20: 158-176.

Karyakin, I. V. et al. 2009a. Imperial Eagle in the Altai Mountains. - Raptors Conserv. 15: 66-79.

Karyakin, I. V. et al. 2009b. Imperial Eagle in the Altai Mountains: Results of the Research in 2009, Russia. — Raptors Conserv. 16: 129-138.

Karyakin, I. V. and Pazhenkov, A. S. 2010. The Imperial Eagle in the Samara District, Russia. - Raptors Conserv. 20: 97-118.

Karyakin, I. V. et al. 2010b. The Imperial Eagle in the Ural Region, Russia. — Raptors Conserv. 20: 128-145.

Katzner, T. E. et al. 2003. Coexistence in a multispecies assemblage of eagles in Central Asia. - Condor 105: 538-551.

Kennedy, P. L. et al. 1995. Breeding biology of the Zone-tailed Hawk at the limit of its distribution. - J. Raptor Res. 29: 110-116.

Kostrzewa, A. 1991. Interspecific interference competition in three European raptor species. - Ethol. Ecol. Evol. 3: 127-143.

Liberatori, F. and Penteriani, V. 2001. A long-term analysis of the declining population of the Egyptian Vulture in the Italian peninsula: distribution, habitat preference, productivity and conservation implications. - Biol. Conserv. 101: 381-389.

Lopez-Lopez, P. et al. 2004. Patrón de distribución del Águila Real Aquila chrysaetos y del Águila-Azor Perdicera Hieraaetus fasciatus en la provincia de Castellón. - Ardeola 51: 275-283. 
Lopez-Lopez, P. et al. 2007. Population size, breeding performance and territory quality of Bonelli's Eagle Hieraaetus fasciatus in eastern Spain. — Bird Study 54: 335-342.

Mahaffy, M. S. and Frenzel, L. D. 1987. Elicited territorial responses of Northern Bald Eagles near active nests. - J. Wildl. Manag. 51: 551-554.

Margalida, A. and Garcia, D. 1999. Nest use, interspecific relationships and competition for nests in the Bearded Vulture Gypaetus barbatus in the Pyrenees: influence on breeding success. — Bird Study 46: 224-229.

Marquiss, M. and Newton, I. 1982. A radio-tracking study of the ranging behavior and dispersion of European Sparrowhawks Accipiter nisus. — J. Anim. Ecol. 51: 111-133.

Martell, M. et al. 1998. Nesting and migration of Swainson's Hawks in Minnesota. — Loon 70: $72-81$.

Martinez, J. E. et al. 2010. Potential impact of wind farms on territories of large eagles in southeastern Spain. — Biodivers. Conserv. 19: 3757-3767.

Martinez, J. E. et al. 2008. The effect of intra- and interspecific interactions on the largescale distribution of cliff-nesting raptors. - Ornis Fenn. 85: 13-21.

McIntyre, C. L. et al. 2006. Characteristics of the landscape surrounding Golden Eagle nest sites in Denali National Park and Preserve, Alaska. - J. Raptor Res. 40: 46-51.

Messenger, A. and Roome, M. 2007. The breeding population of the Hobby in Derbyshire. — Br. Birds 100: 594-608.

Mooney, N. J. and Brothers, N. P. 1987. The Peregrine Falcon, Falco peregrinus macropus $\mathrm{S}$, in Tasmania. 1. Distribution, abundance and physical characteristics of nests. - Aust. Wildl. Res. 14: 81-93.

Moorman, C. E. and Chapman, B. R. 1996. Nest-site selection of Red-shouldered and Redtailed Hawks in a managed forest. — Wilson Bull. 108: 357-368.

Morneau, F. et al. 1994. Abundance and distribution of nesting Golden Eagles in HudsonBay, Quebec. — J. Raptor Res. 28: 220-225.

Mougeot, F. and Bretagnolle, V. 2006. Breeding biology of the Red Kite Milvus milvus in Corsica. - Ibis 148: 436-448. 
Muñoz, A. 1993. Situació dels Falconiformes nidificants a la Peninsula de Llevant de Mallorca. - Anuari Ornitol Balears 8: 31-38.

Newton, I. et al. 1986. Spacing of Sparrowhawks in relation to food-supply. - J. Anim. Ecol. 55: 361-370.

Nielsen, J. T. 2004. Spurvehogens Accipiter nisus bestandsudvikling, ynglehabitat, alderssammensaetning og ungeproduktion i Vendsyssel, 1977-97. — Dan. Ornitol. Foren. Tidsskr. 98: 147-162.

Nilsson, I. N. et al. 1982. Diet choice, resource depression, and the regular nest spacing of birds of prey. - Biol. J. Linn. Soc. 18: 1-9.

Obst, J. 1994. Tree nesting by the Gyrfalcon (Falco rusticolus) in the Western Canadian Arctic. - J. Raptor Res. 28: 4-8.

Olsen, P. D. and Olsen, J. 1988. Breeding of the Peregrine Falcon Falco peregrinus. 1. Weather, nest spacing and territory occupancy. — Emu 88: 195-201.

Panasci, T. A. and Whitacre, D. F. 2002. Roadside Hawk breeding ecology in forest and farming landscapes. - Wilson Bull. 114: 114-121.

Pedrini, P. and Sergio, F. 2001. Density, productivity, diet, and human persecution of Golden Eagles (Aquila chrysaetos) in the central-eastern Italian Alps. - J. Raptor Res. 35: 40-48.

Pennycuick, C. J. and Kline, N. C. 1986. Units of measurement for fractal extent, applied to the coastal distribution of Bald Eagle nests in the Aleutian Islands, Alaska. — Oecologia 68: $254-258$.

Penteriani, V. 1997. Long-term study of a Goshawk breeding population on a Mediterranean mountain (Abruzzi apennines, central Italy): Density, breeding performance and diet. — J. Raptor Res. 31: 308-312.

Penteriani, V. et al. 2001. An approach to identify factors and levels of nesting habitat selection: a cross-scale analysis of Goshawk preferences. — Ornis Fenn. 78: 159-167.

Penteriani, V. et al. 2002. Immediate species responses to catastrophic natural disturbances: Windthrow effects on density, productivity, nesting stand choice, and fidelity in 
Northern Goshawks (Accipiter gentilis). — Auk 119: 1132-1137.

Pepler, D. et al. 2001. Estimating the breeding population of Booted Eagles in the Cape Province, South Africa. — J. Raptor Res. 35: 15-19.

Quinn, J. L. and Kokorev, Y. 2000. Direct and indirect estimates of Peregrine Falcon population size in northern Eurasia. — Auk 117: 455-464.

Radovic, A. and Mikuska, T. 2009. Population size, distribution and habitat selection of the White-tailed Eagle Haliaeetus albicilla in the alluvial wetlands of Croatia. - Biologia 64: 156-164.

Reynolds, R. T. et al. 2005. Sampling considerations for demographic and habitat studies of Northern Goshawks. — J. Raptor Res. 39: 274-285.

Reynolds, R. T. and Wight, H. M. 1978. Distribution, density, and productivity of Accipiter hawks breeding in Oregon. - Wilson Bull. 90: 182-196.

Ritchie, R. J. and Shook, J. E. 2011. Recovery and trends of Peregrine Falcons breeding in the Yukon-Tanana Uplands, East-Central Alaska, 1995-2003. — J. Raptor Res. 45: 150159.

Rizzolli, F. et al. 2005. Density, productivity, diet and population status of the Peregrine Falcon Falco peregrinus in the Italian Alps. — Bird Study 52: 188-192.

Rodriguez-Estrella, R. 2000. Breeding success, nest-site characteristics, and diet of Swainson's Hawk (Buteo swainsoni) in a stable population in northern Mexico. - Can. J. Zool. 78: 1052-1059.

Rodríguez, B. and Siverio, M. 2006. Density and breeding habitat characteristics of an insular population of Barbary Falcon Falcon peregrinus peregrinus (E1 Hierro, Canary Islands). — Ardeola 53: 325-331.

Rutz, C. et al. 2006. Population limitation in the Northern Goshawk in Europe: a review with case studies. — Stud. Avian Biol. 31: 158-197.

Sadoti, G. 2008. Nest-site selection by Common Black-Hawks in southwestern New Mexico. — J. Field Ornithol. 79: 11-19.

Sara, M. and Di Vittori, M. 2003. Factors influencing the distribution, abundance and nest- 
site selection of an endangered Egyptian Vulture (Neophron percnopterus) population in Sicily. - Anim. Conserv. 6: 317-328.

Scheller, W. et al. 2001. Verbreitung, Bestandsentwicklung und Lebensraumsituation des Schreiadlers Aquila pomarina in Mecklenburg-Vorpommern. — Vogelwelt 122: 233246.

Schoegel, J. 2007. Hohe Siedlungsdichte des Baumfalken Falco subbuteo im Unterallgaeu. - Ornithol. Anz. 46: 63-67.

Schulze, M. D. and Cordova, J. L. 2000. Behavior, diet, and breeding biology of Doubletoothed Kites at a Guatemalan lowland site. - Condor 102: 113-126.

Seavy, N. E. et al. 1998. Breeding biology and behavior of the Plumbeous Kite. - Wilson Bull. 110: 77-85.

Selas, V. 1997a. Breeding density of Sparrowhawk Accipiter nisus in relation to nest site availability, hatching success and winter weather. — Ornis Fenn. 74: 121-129.

Selas, V. 1997b. Influence of prey availability on re-establishment of Goshawk Accipiter gentilis nesting territories. - Ornis Fenn. 74: 113-120.

Selas, V. 1998. Does food competition from Red Fox (Vulpes vulpes) influence the breeding density of Goshawk (Accipiter gentilis)? Evidence from a natural experiment. — J. Zool. (Lond.) 246: 325-335.

Sergio, F. et al. 2005. Preservation of wide-ranging top predators by site-protection: Black and Red Kites in Donana National Park. - Biol. Conserv. 125: 11-21.

Sergio, F. and Bogliani, G. 1999. Eurasian Hobby density, nest area occupancy, diet, and productivity in relation to intensive agriculture. - Condor 101: 806-817.

Siverio, M. et al. 2011. Long-term monitoring of an insular population of Barbary Falcon Falco peregrinus pelegrinoides. — Ostrich 82: 225-230.

Sodhi, N. S. et al. 1992. Breeding ecology of urban Merlins (Falco columbarius). - Can. J. Zool. 70: 1477-1483.

Solonen, T. 1993. Spacing of birds of prey in Southern Finland. — Ornis Fenn. 70: 129143. 
Steenhof, K. et al. 1999. Long-term Prairie Falcon population changes in relation to prey abundance, weather, land uses, and habitat conditions. — Condor 101: 28-41.

Stewart, R. E. 1949. Ecology of a nesting Red-shouldered Hawk population. - Wilson Bull. 61: 26-35.

Stoj, M. 2008. Rozmieszczenie, liczebnosc i wybrane aspekty ekologii rozrodu orla przedniego Aquila chrysaetos w polskiej czesci Karpat w latach 1997-2007. — Notatki Ornitol. 49: 1-12.

Stout, W. E. et al. 1998. Urban, suburban and rural Red-tailed Hawk nesting habitat and populations in southeast Wisconsin. - J. Raptor Res. 32: 221-228.

Stout, W. E. and Rosenfield, R. N. 2010. Colonization, growth, and density of a pioneer Cooper's Hawk population in a large metropolitan environment. - J. Raptor Res. 44: 255-267.

Suarez, S. et al. 2000. Nesting habitat selection by Booted Eagles Hieraaetus pennatus and implications for management. - J. Appl. Ecol. 37: 215-223.

Tjernberg, M. 1985. Spacing of Golden Eagle Aquila chrysaetos nests in relation to nest site and food availability. — Ibis 127: 250-255.

Uchida, H. et al. 2007. Breeding ecology of Northern Goshawk at hilly terrain area in central Japan. — Jpn. J. Ornithol. 56: 131-140.

Vargas-Gónzalez, J. D. and Vargas, F. H. 2011. Nesting density of Harpy Eagles in Darien with population size estimates for Panama. — J. Raptor Res. 45: 199-210.

Vargas-Gónzalez, J. d. J. et al. 2006. Estado y distribución actual del Águila Arpía (Harpia harpyja) en Centro y Sur América. — Ornitol. Neotrop. 17: 39-55.

Verdejo, J. and Lopez-Lopez, P. 2008. Long-term monitoring of a Peregrine Falcon population: size, breeding performance and nest-site characteristics. — Ardeola 55: 8796.

Watson, A. and Rothery, P. 1986. Regularity in spacing of Golden Eagle Aquila chrysaetos nests used within years in Northeast Scotland. - Ibis 128: 406-408.

Whitaker, D. M. et al. 1996. Breeding season irruptions of Rough-legged Hawks (Buteo 
lagopus) on insular Newfoundland. - Arctic 49: 306-310.

White, C. M. et al. 1981. The status and distribution of de Peregrine Falcon in Victoria, Australia. - Emu 80: 270-280.

Widen, P. 1985. Breeding and movements of Goshawks in boreal forests in Sweden. Holarct. Ecol. 8: 273-279.

Wightman, C. S. and Fuller, M. R. 2005. Spacing and physical habitat selection patterns of Peregrine Falcons in central West Greenland. — Wilson Bull. 117: 226-236.

Wiklund, C. G. et al. 1998. Mechanisms determining the spatial distribution of microtine predators on the Arctic tundra. - J. Anim. Ecol. 67: 91-98.

Wright, P. M. 1997. Distribution, site occupancy and breeding success of the Merlin Falco columbarius on Barden moor and fell, north Yorkshire. — Bird Study 44: 182-193.

Wyllie, I. and Newton, I. 1991. Demography of an increasing population of Sparrowhawks. — J. Anim. Ecol. 60: 749-766.

Zawadzka, D. and Zawadzki, J. 1998. The Goshawk Accipiter gentilis in Wigry National Park (NE Poland)- numbers, breeding results, diet composition and prey selection. Acta Ornithol. 33: 181-190.

Zawadzka, D. et al. 2006. Rozwoj populacji, wymagania srodowiskowe i ekologia bielika Haliaeetus albicilla w Puszczy Augustowskiej. — Notatki Ornitol. 47: 217-229. 
Supplementary material for "Structural complexity of hunting habitat and territoriality increase the reversed sexual dimorphism in diurnal raptors".

(a)

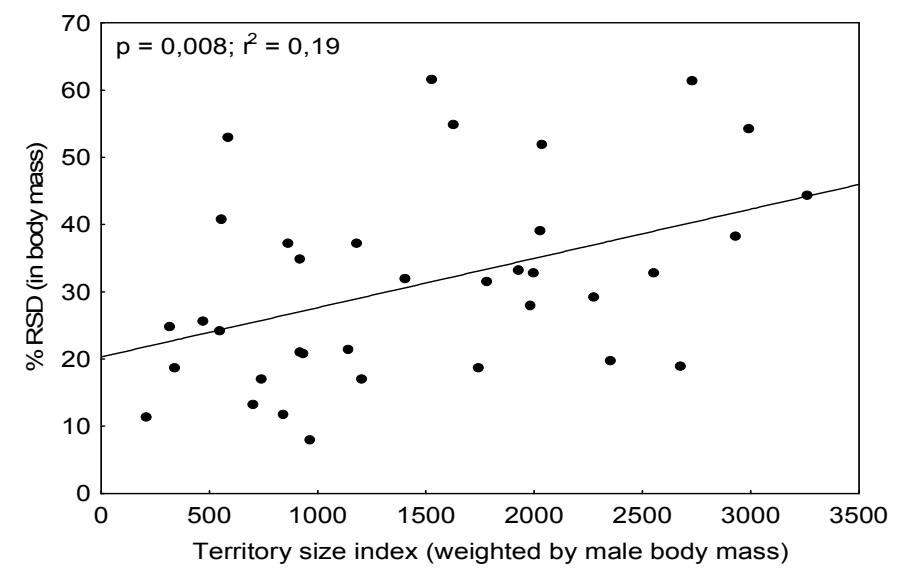

(b)

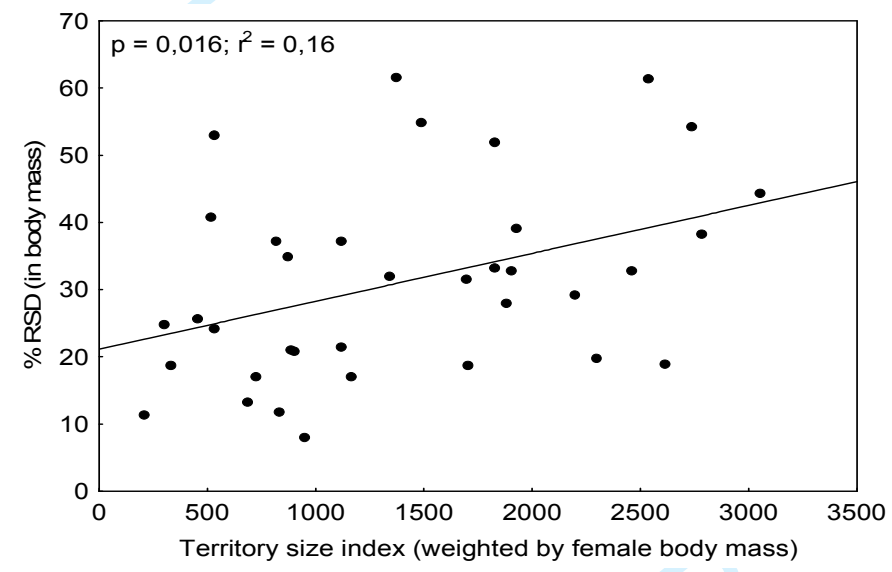

(c)

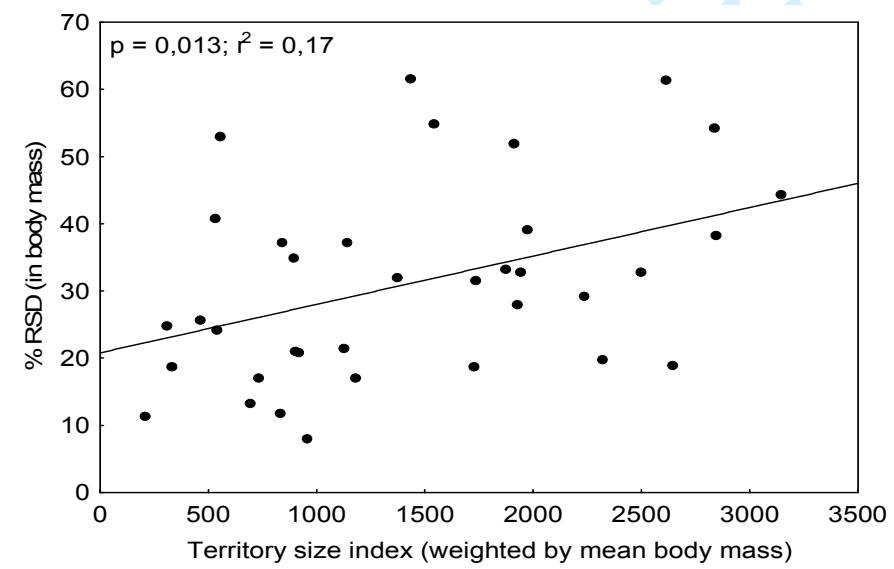

Appendix 2. Figure A1. 
Figure A1. Relationship between RSD in New World and Western Palearctic raptors and territory size index (average nearest-neighbour inter-nest distance in the population/ $\log _{10}$ (body mass)) using body mass of: (a) male; (b) female; and (c) mean of both sexes. 


\section{Supplementary material for "Structural complexity of hunting habitat and territoriality increase the reversed sexual dimorphism in diurnal raptors".}

Appendix 3. Table A1 and Figures A1-A4.

Table A1. Proportions of RSD variation explained $\left(\mathrm{R}^{2}\right)$ individually and jointly by agility of the main prey, hunting habitat structure and territoriality or territory size. These data are summarised in Figure 3.

\begin{tabular}{lcc}
\hline & $\begin{array}{c}\text { All raptors } \\
(75 \text { species })\end{array}$ & $\begin{array}{c}\text { Territorial raptors } \\
(36 \text { species })\end{array}$ \\
\hline Total & 0.513 & 0.398 \\
Prey agility & 0.433 & 0.292 \\
Hunting habitat & 0.108 & 0.058 \\
Territoriality & 0.160 & \\
Territory size & & 0.188 \\
Prey agility \& Hunting habitat & 0.035 & -0.037 \\
Prey agility \& Territoriality & 0.141 & \\
Prey agility \& Territory size & & 0.167 \\
Hunting habitat \& Territoriality & 0.042 & \\
Hunting habitat \& Territory size & & -0.064 \\
Prey agility \& Hunting habitat \& Territoriality & 0.032 & \\
Prey agility \& Hunting habitat \& Territory size & & -0.041 \\
\hline
\end{tabular}


(a)

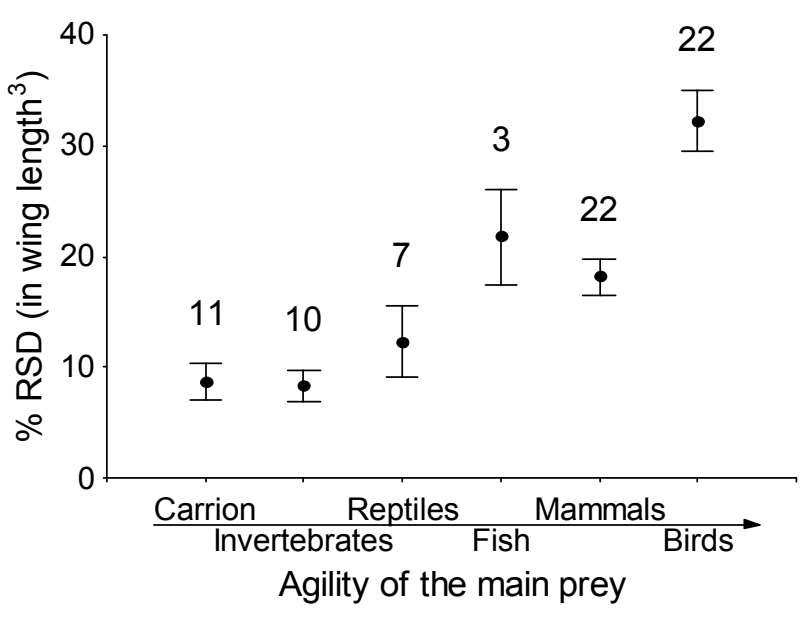

(b)

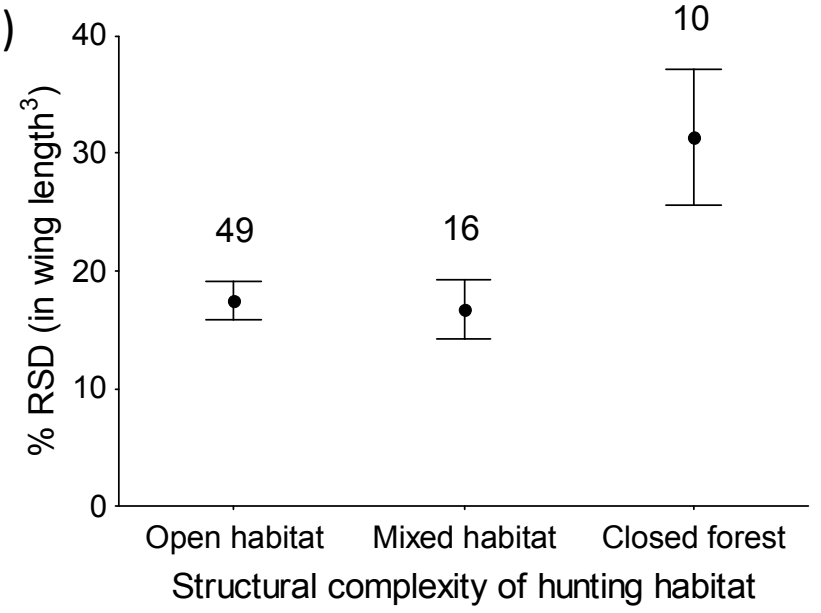

(c)

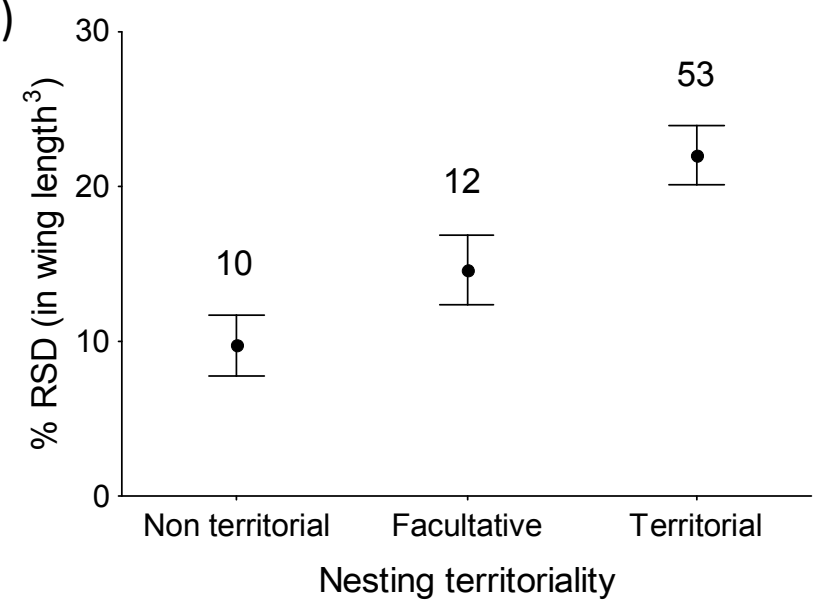

Figure A1. RSD of New World and Western Palearctic raptors was measured in terms of the cubed wing length and depicted as a function of: (a) agility of the main prey; (b) hunting habitat in breading season; and (c) territorial nesting behaviour. Error bars indicate 1 S.E. and number above bars the number of raptor species. 


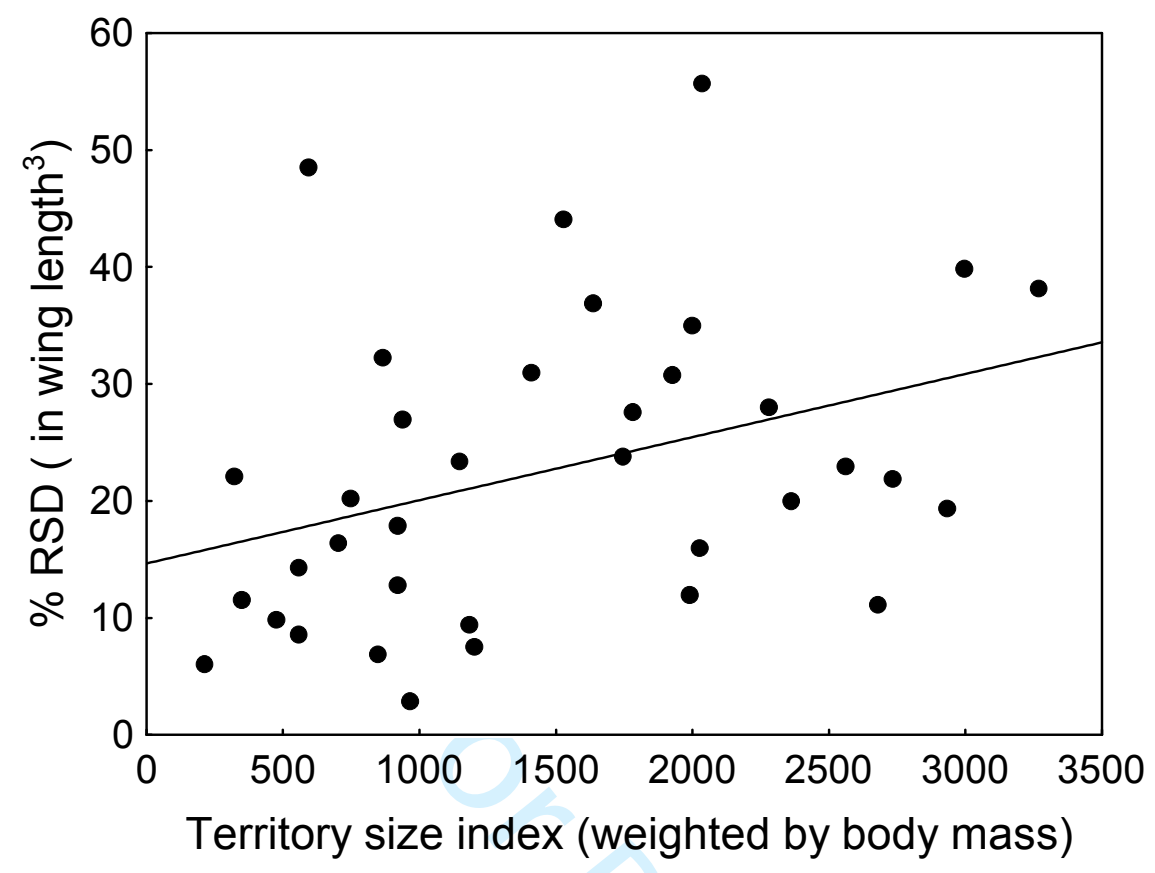

Figure A2. RSD of New World and Western Palearctic raptors was measured in terms of the cubed wing length and depicted as a function of territory size index: average nearestneighbour inter-nest distance in the population $/ \log _{10}$ (mean male body mass). 


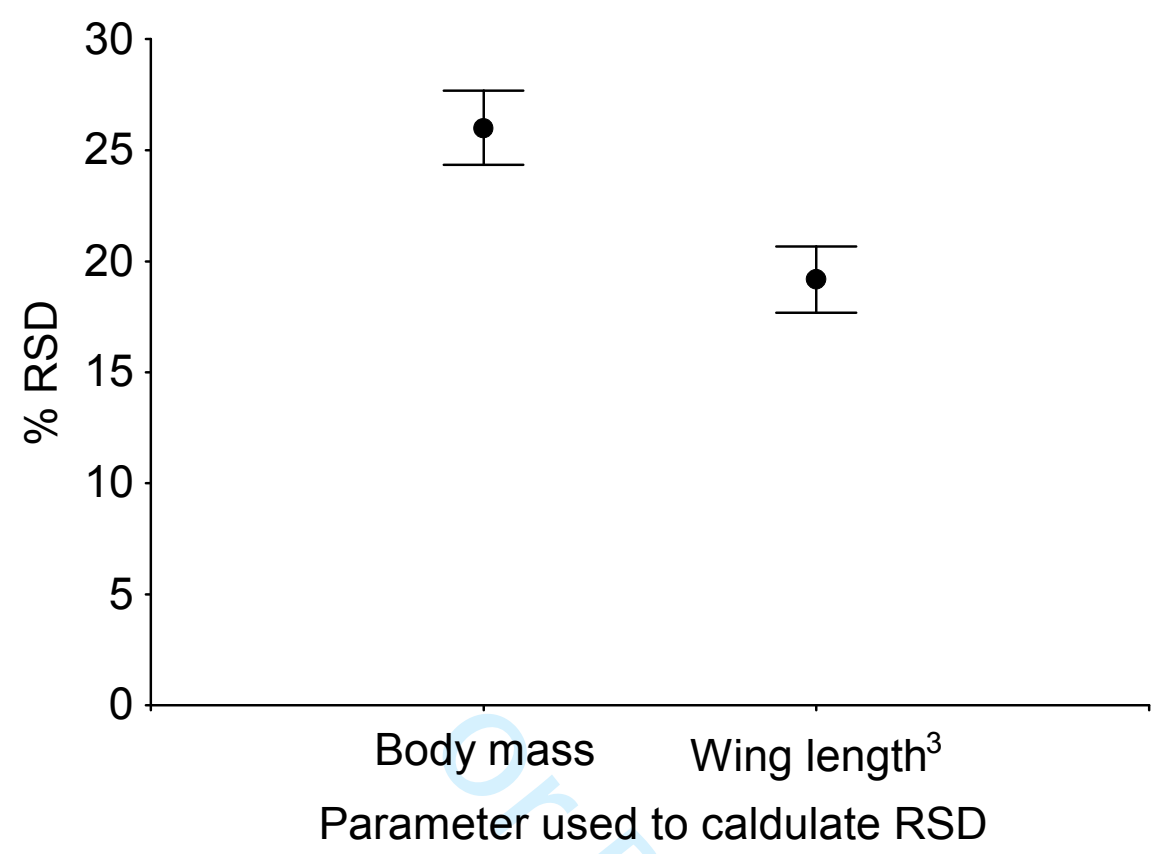

Figure A3. Comparison of RSD calculated based on body mass and RSD calculated based on cubic wing length for New World and Western Palearctic raptors. Error bars indicate 1 S.E. 


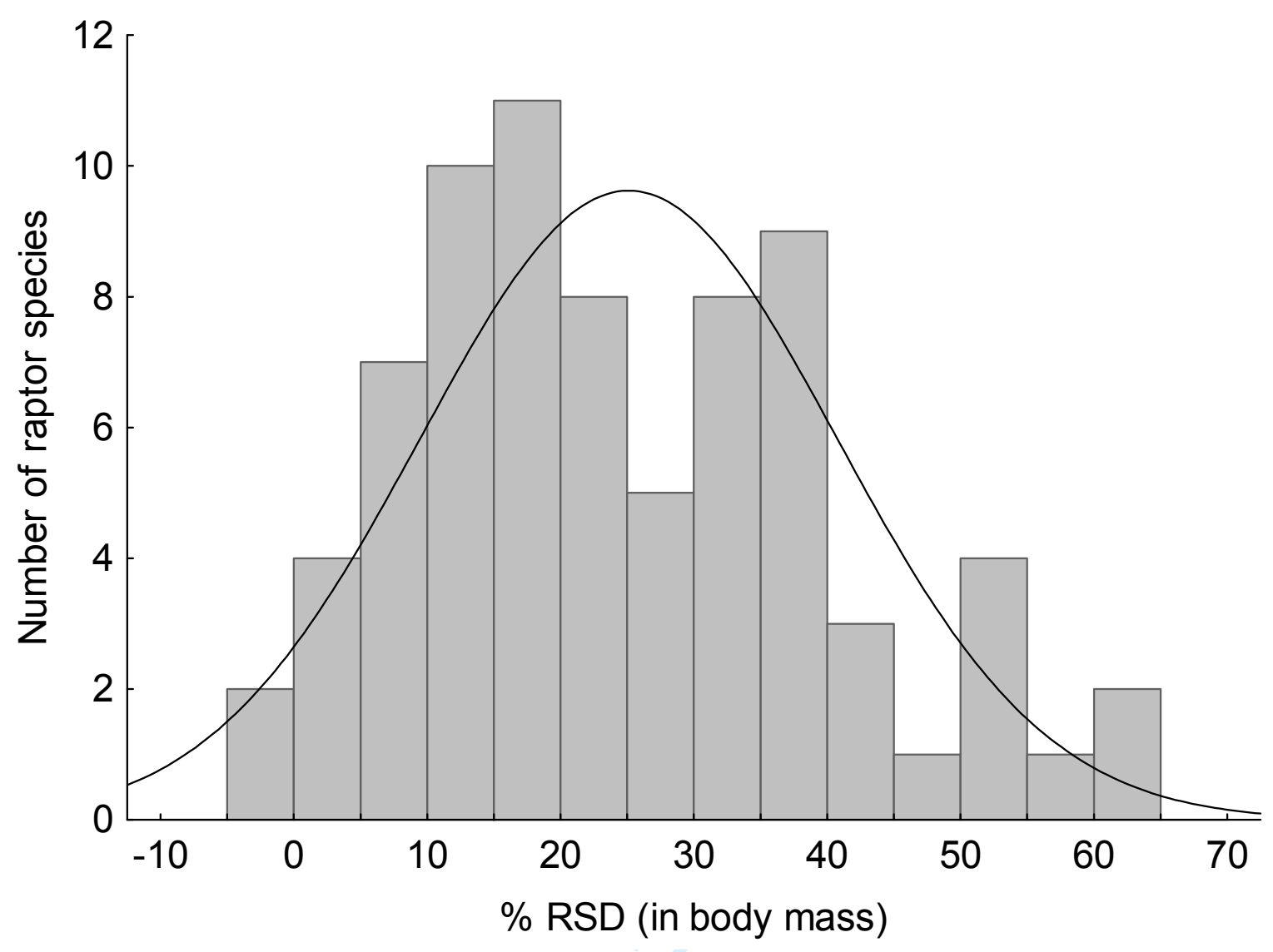

Figure A4. Histogram of the distribution of RSD in the studied raptor species. The line show the normal distribution. 
Supplementary material for "Structural complexity of hunting habitat and territoriality increase the reversed sexual dimorphism in diurnal raptors".

\section{Appendix 4. Table A1.}

Table A1. Generalized Linear Mixed Models (GLMM) with (i.e. GLMM.phylo) and without (i.e. GLMM) a random effect characterizing the phylogenetic relationships among species. Models are fitted within a Bayesian framework that uses Markov Chain Monte Carlo (MCMC) methods instead of adjusting maximum likelihood (Hadfield and Nakagawa 2010). Posterior means of coefficients together with their $95 \%$ Confidence Intervals are indicated for each predictor. Also, the Deviance Information Criterion (DIC) of each model is reported. Models were fit using a thinning interval of 10 a burn-in period of 3,000 iterations, and 17,000 iterations for models to converge. We report fixed effects to allow direct comparison against OLS and PGLS results. Results qualitatively coincide with those yielded by OLS and PGLS models in identifying prey agility and hunting habitat as significant predictors and, models accounting for phylogenetic relationships as showing better fits than non-phylogenetic models.

\begin{tabular}{|c|c|c|c|c|c|c|c|c|c|c|c|c|c|}
\hline \multirow[b]{2}{*}{ Model } & \multicolumn{3}{|c|}{$\begin{array}{c}\text { Hunting } \\
\text { habitat }\end{array}$} & \multicolumn{4}{|c|}{$\begin{array}{l}\text { Prey } \\
\text { agility }\end{array}$} & \multicolumn{4}{|c|}{ Territoriality / Territory size } & \multirow[b]{2}{*}{$P$} & \multirow[b]{2}{*}{$D I C$} \\
\hline & $\begin{array}{c}\text { posterior } \\
\text { mean }\end{array}$ & $\begin{array}{c}\text { low } 95 \% \\
\text { CI }\end{array}$ & $\begin{array}{c}\text { up } 95 \% \\
\text { CI }\end{array}$ & $P$ & $\begin{array}{c}\text { posterior } \\
\text { mean }\end{array}$ & $\begin{array}{c}\text { low } 95 \% \\
\text { CI }\end{array}$ & $\begin{array}{c}\text { up } 95 \% \\
\text { CI }\end{array}$ & $P$ & $\begin{array}{c}\text { posterior } \\
\text { mean }\end{array}$ & $\begin{array}{c}\text { low } 95 \% \\
\text { CI }\end{array}$ & $\begin{array}{c}\text { up } 95 \% \\
\text { CI }\end{array}$ & & \\
\hline GLMM (75sp.) & 5.113 & 1.701 & 8.451 & 0.003 & 4.586 & 3.184 & 5.884 & 0.001 & 2.108 & -1.887 & 5.857 & 0.261 & 568.655 \\
\hline GLMM.phylo (75sp.) & 5.114 & 1.575 & 8.727 & 0.006 & 4.347 & 2.780 & 5.725 & 0.001 & 2.679 & -0.706 & 6.629 & 0.147 & 563.094 \\
\hline GLMM (36sp.) & 6.923 & 1.775 & 12.522 & 0.011 & 4.411 & 1.135 & 7.941 & 0.007 & 0.005 & -0.001 & 0.010 & 0.116 & 283.572 \\
\hline GLMM.phylo (36sp.) & 6.989 & 1.892 & 13.240 & 0.020 & 4.356 & 0.772 & 7.362 & 0.011 & 0.004 & -0.001 & 0.010 & 0.121 & 282.911 \\
\hline
\end{tabular}

